\title{
Working
}

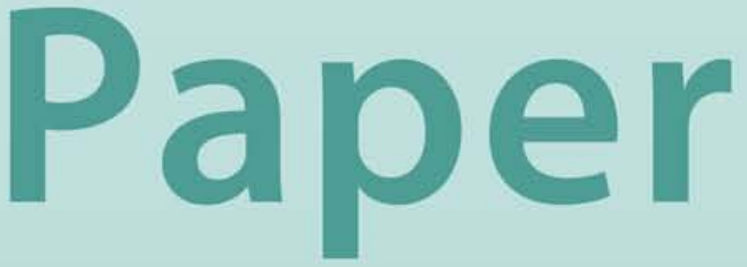


Investment by Large Firms in Argentina

Alvaro Piris 


\title{
IMF Working Paper
}

WHD

\section{Investment by Large Firms in Argentina}

\section{Prepared by Alvaro Piris ${ }^{1}$}

Authorized for distribution by Robert Rennhack

January 2010

\begin{abstract}
This Working Paper should not be reported as representing the views of the IMF. The views expressed in this Working Paper are those of the author(s) and do not necessarily represent those of the IMF or IMF policy. Working Papers describe research in progress by the author(s) and are published to elicit comments and to further debate.

Strong growth in investment made a key contribution to the economic recovery in Argentina earlier this decade. The paper uses firm-level data to assess changes in financing constraints and the linkages between real investment at the firm level and macroeconomic developments in the real exchange rate and real interest rates. It concludes that several factors explain the performance of investment, including the real exchange rate, the cost of borrowing as well as an easing of financing constraints.

JEL Classification Numbers:XXX

Keywords: Argentina, investment

Author's E-Mail Address:apiris@imf.org

\footnotetext{
${ }^{1}$ The author thanks Pelin Berkmen, Gaston Gelos, Nigel Chalk, Herman Kamil, Vikram Haksar, Jingqing Chai, Ana Corbacho, Kornelia Krajnyak, Robert Rennhack, Guillermo Tolosa and participants in a seminar held at the Western Hemisphere department of the IMF for comments. Eugen Tereanu and Ben Sutton offered assistance with estimation, and Emory Ventura and Duong He with the Economatica database. Remaining errors are my own.
} 


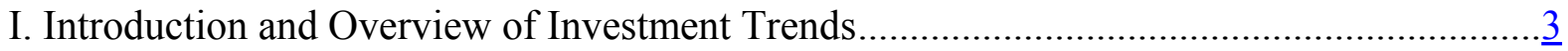

A. Macroeconomic Developments and Aggregate Investment …............................

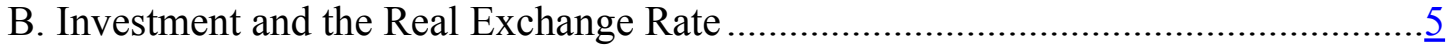

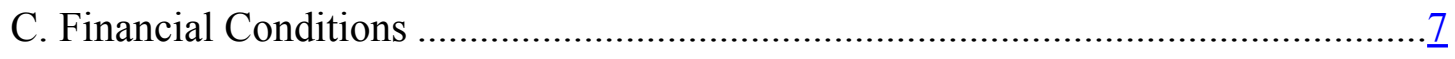

II. Investment Behavior at the Firm Level..................................................................

A. Estimating Investment Equations in the Presence of Financial Constraints .............

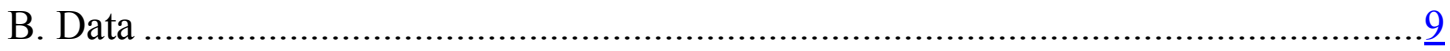

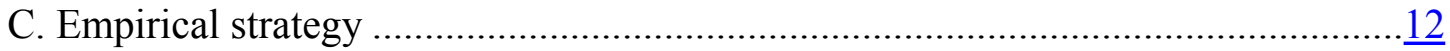

D. Specification Problems and Endogeneity ....................................................

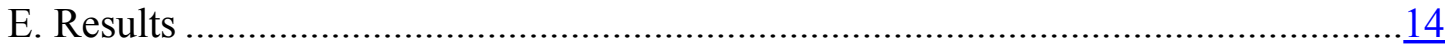

F. Dealing with Specification Problems …...................................................... 17

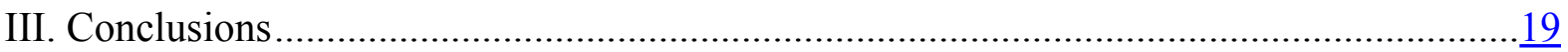

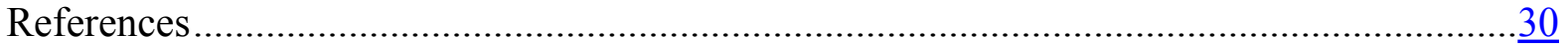

Tables

1. Exposure to Relative Price Changes by Sector .............................................................. $\underline{5}$

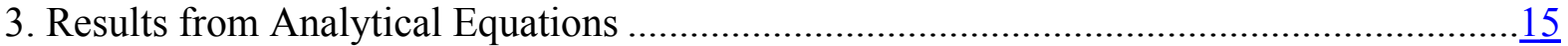

Figures

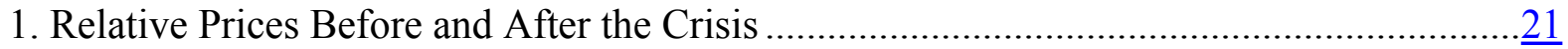

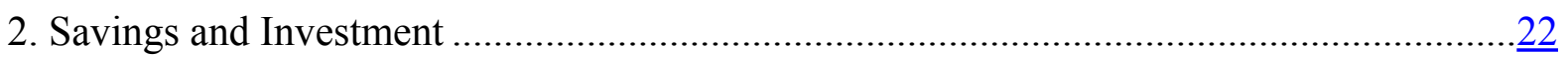

3. Aggregate Investment: Regional Comparison ......................................................

4. Aggregate Returns to Capital and Labor ...................................................................24

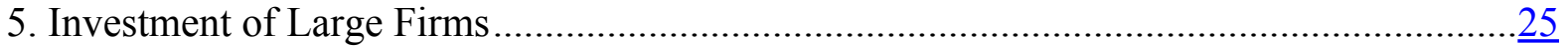

Annexes

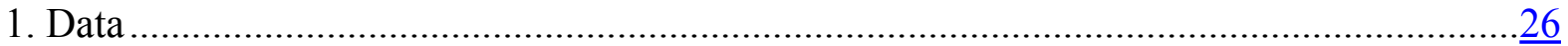

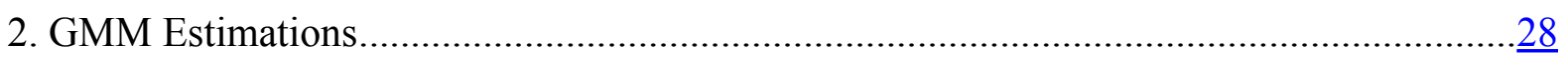

Annex Table

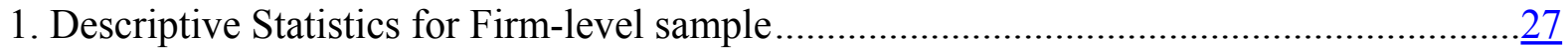

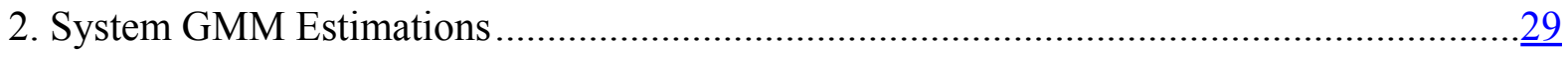




\section{INTRODUCTION AND OVERVIEW OF INVESTMENT TRENDS}

Following the crisis earlier this decade, aggregate investment in Argentina rose sharply, helping to spur the vigorous recovery in economic growth since 2002. The investment environment changed significantly as the economy recovered, notably through significant real exchange rate depreciation, negative real interest rates and increased international demand for argentine products. Financial conditions were affected by sovereign default and banking crisis.

This paper analyzes the impact of the changing economic environment on investment decisions of large firms. Using a panel of balance sheet data for just under 90 listed firms, investment is linked to a measure of the productivity of capital, a proxy for financing constraints and key macroeconomic variables such as the real exchange rate and the cost of borrowing. Investment is found to be positively correlated with a more appreciated real exchange rate, indicating that for the large, listed firms considered here, the benefit of cheaper imported inputs and easier servicing of dollar-denominated debt outweigh the lower peso value of their exports. The effect on investment is halved for firms in the traded goods sector, consistent with the observation that firms in tradable sectors invested more than others after 2002. Regarding financial conditions, a firm-specific effective interest rate measure is developed, and is found to be a significant determinant of investment. There is some evidence consistent with an increased impact of financing constraints - that is, limited access to financing external to the firm - on investment decisions after the 2001 crisis. It can be noted that this evidence is not inconsistent with the hypothesis of some analysts that the postcrisis environment favored the growth of small and medium firms in the tradable sector using labor-intensive production techniques. However, this question is not addressed in this paper.

The rest of this section provides a short descriptive overview of developments in aggregate investment and relevant macroeconomic variables over the relevant period, and a brief consideration of the relationship between investment and two key relative prices considered in the paper (the real exchange rate and financing costs). The second section presents the model and estimation results for the panel estimations. The final section concludes.

\section{A. Macroeconomic Developments and Aggregate Investment}

The 1990s in Argentina was a period of relative economic stability, punctuated by a brief recession in 1995 and more acute economic decline starting in 1998 that eventually culminated in an economic crisis in 2001/2002. This crisis - with a cumulative fall in real GDP of 18 percent between 1998 and 2002 - also represented a rupture in policy regime, with the fixed exchange rate system giving way to a floating exchange rate, a sovereign debt default and forcible

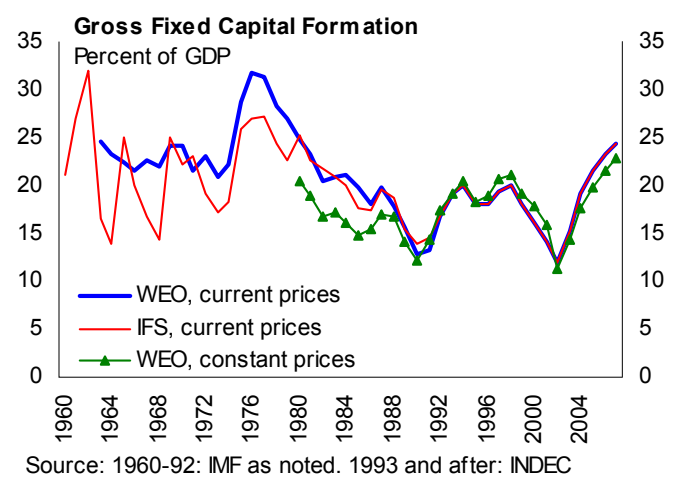


conversion of previously dollar-denominated financial contracts to pesos. The relatively stable real exchange rate had previously acted as a bellwether of confidence and anchored price expectations.

Recovery was nonetheless swift, aided by a favorable external environment and supportive policy. Fiscal and external deficits were reversed into substantial surpluses, and new investment opportunities arose both domestically and as global demand for Argentine products rose, particularly commodities. Key relative prices changed, including a real depreciation of the peso, real wage erosion, and declines in real energy costs, while shortterm real interest rates became negative (Figure 1).

After 2001, gross fixed capital formation (GFCF) rose steadily as a proportion of GDP (see Chart, and Figure 2). ${ }^{2}$ Nonetheless, the ratio remained well within the range of values in Latin America and is low compared with other emerging markets (Figure 3). The growth in investment was led by construction, especially in the residential sector (motivated by a long period of vigorous growth in property prices, and by demand for real estate as an inflation hedge). Investment in vehicles, equipment and machinery - usually argued to be a much more important determinant of productivity growth ${ }^{3}$ - recovered more slowly, and capital stock per worker declined substantially from pre-2002 peaks. ${ }^{4}$ Furthermore, machinery has a much higher depreciation rate than physical structures making the effect of the relative decline of machinery to construction on total capital per worker all the more acute. ${ }^{5}$

\footnotetext{
${ }^{2}$ Data from periods prior to 1993 are volatile, with differences between sources. Using constant price data starting in 1980, the IMF WEO database shows current ratios are the highest they have been, while data from FIEL (an Argentine economic consulting group citing the BCRA as source), has maxima in 1980-81 and higher ratios throughout—including post-1993. Current price data, for which longer series are available, from the IFS and WEO databases give differing pictures for the period 1963 to 1979.

${ }^{3}$ De Long and Summers (1991).

${ }^{4}$ The recovery in durable goods investment is faster when the ratio to GDP is measured in current price terms, due to price effects from the devaluation on imported capital goods, which probably substantially exaggerated the creation of new physical capital in the early post-crisis. Two measures of the capital stock are available, from INDEC and a Ministry of Economy study by Maia and Nicholson (2005). There is a significant difference in levels, but the series have similar variations.

${ }^{5}$ In constructing a capital stock series for Argentina, Maia and Nicholson (2005) use 17 percent depreciation for durable goods versus 3 percent for construction.
} 

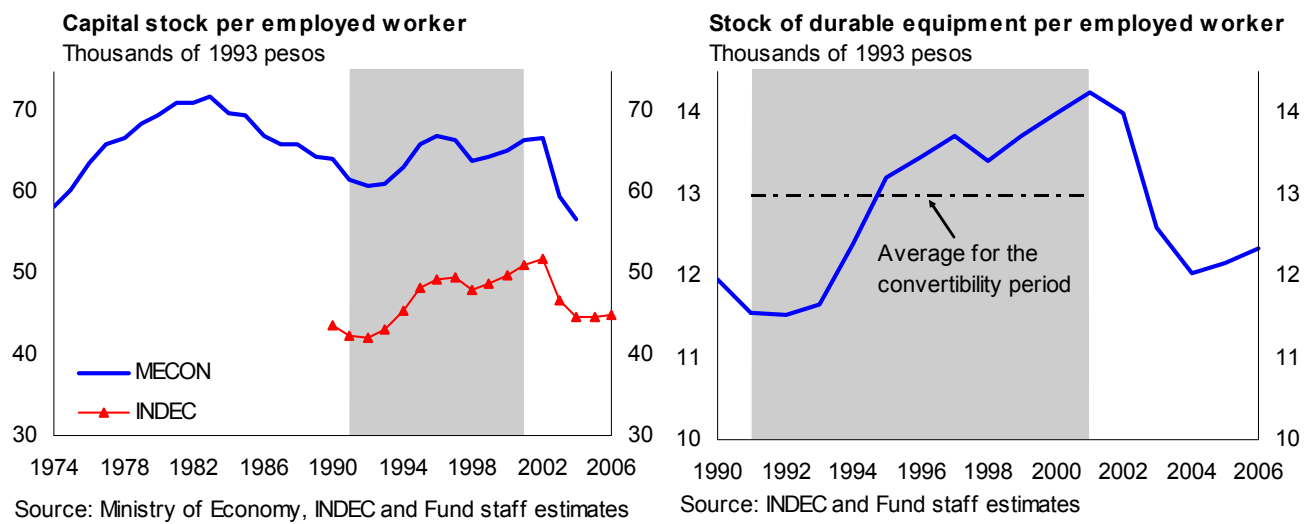

The sharp changes in relative prices affected investment incentives differently across sectors. Table 1 shows the exposure of several sectors to real exchange rate and energy price changes, using data from input-output matrices for 1997. These data indicate that the most tradeintensive sectors are primary extractive industries and manufacturing, while many manufacturing industries, mining and some services are also energy-intensive (measured as electricity inputs as a proportion of gross production).

\begin{tabular}{lrrr}
\multicolumn{5}{c}{$\begin{array}{c}\text { Table 1. Exposure to Relative Price Changes by Sector, } 1997 \\
\text { (In percent of gross production) }\end{array}$} \\
\hline Exports & Imports & Electricity use \\
\hline Agriculture and fishery & 14.5 & 2.1 & 0.6 \\
Mining & 25.5 & 2.1 & 1.4 \\
Extraction of metals & 36.9 & 15.3 & 23.6 \\
Manufacturing & 14.4 & 10.6 & 0.9 \\
Oils and their subproducts & 82.2 & 5.1 & 0.6 \\
Motor vehicles & 36.2 & 38.3 & 0.3 \\
Other secondary & 0.0 & 2.8 & 0.8 \\
Services & 1.2 & 1.1 & 0.8 \\
Air transport & 4.1 & 17.4 & 4.5 \\
Total & $\mathbf{6 . 3}$ & $\mathbf{4 . 1}$ & $\mathbf{0 . 9}$ \\
\hline Source: INDEC & & &
\end{tabular}

\section{B. Investment and the Real Exchange Rate}

Real depreciation affects profitability - and thus investment incentives - at the firm level through the share of exports in sales, the reliance on imported products in production and the impact on foreign-currency debt service. ${ }^{6}$ As might be expected, the devaluation resulted in a sharp rise in the value added (and income accruing to capital) generated by tradable activities

\footnotetext{
${ }^{6}$ Campa and Goldberg (1995), using sectoral level data for the US, find important differences in the impact of the exchange rate on investment between sectors, depending on these factors and specific pass-through and demand elasticities for each industry. A further consideration is that acquisitions of existing local assets and new investments by foreign firms may be facilitated by low prices measured in their home currencies after depreciations - but the expected rate of return, would likewise be depressed. Acosta and Loza (2005) and McCulloch (1989) touch on these issues.
} 
(Figure 4). Prices in mining, agriculture and manufacturing, as measured by sectoral deflators, increased far more rapidly than for services and other secondary activities. Value added per hour worked in US dollars barely dipped in mining and agriculture, with the latter sector rising well above the average level for the economy. These trends were aided by rising commodity prices over the period.

This pattern is evident in data on the 500 largest firms (Figure 5). ${ }^{7}$ These firms are concentrated in tradable sectors - in 2005, 75 percent of the value added they generated was in mining and manufacturing, compared to 26 percent in total gross value added. Their production, value added and profits jumped after the devaluation, with the mining sector a clear outlier. Firms in non-tradable sectors, particularly communications and electricity and gas, subject to price regulation, made losses in the post-crisis period. Turning to industrial production, output and capacity utilization data can be used to infer that the manufacturing subsectors that most increased installed capacity - paper and cardboard, motor vehicles and chemical products - were among those increasing exports the most.

In terms of firms' inputs, prior to the crisis, imports of capital goods were equivalent to half the value of durable goods investment (Figure 2). On devaluation, the fall in imported capital goods accounted for more than three-quarters of the fall in durable goods investment. As the economy recovered, however, capital goods imports grew as a proportion of total durable goods investment to exceed previous peaks.

Extensive debt dollarization prior to the crisis did not undermine profitability. Dollarization of domestic financial institutions' credit to the private sector had risen to 72 percent by 2001 . For the 500 largest firms, the burden of servicing this debt — already rising steadily through the later convertibility period-jumped by $2 \frac{1}{2}$ percent of GDP on devaluation (Figure 5). However, financial expenses then declined rapidly, reflecting the benefits to firms of "asymmetric pesification"-bank dollar assets and liabilities were redenominated into pesos at differing rates, favorable to debtors - which short-circuited the balance-sheet channels by which devaluation can undermine corporate health.

\footnotetext{
${ }^{7}$ These firms accounted for about 20 percent of gross value added. The data is published by INDEC, but is only available up until 2003 to 2005, depending on the item, and is published in aggregated form: individual firms cannot be identified.
} 


\section{Financial Conditions}

Despite the policy-led fall in short-term real interest rates, financial conditions facing firms worsened in the aftermath of the crisis. Sovereign default and asymmetric pesification provoked a banking crisis and curtailed access to foreign financing. Domestic capital markets were affected by increased uncertainty. Bank lending (the dominant source of firm financing) was weak for several years, and restructuring of dollarized corporate debt was often a long drawn out process. Restrictions on dollar lending or indexation of debt to prices or the exchange rate also contributed to a reduction in long-term credit, and dollar lending did not

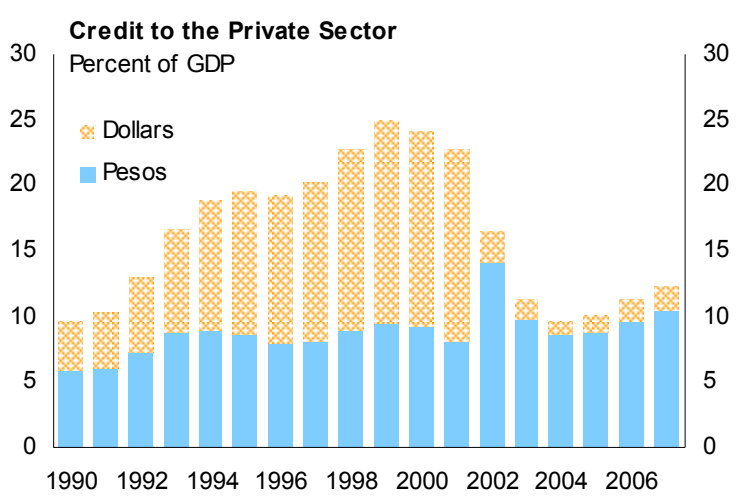
recover. The decline in aggregate credit despite the recovery makes a strong prima facie case that financing constraints became worse and credit rationing became more prevalent until 2006.

\section{INVESTMENT BEHAVIOR AT THE FIRM LEVEL}

This section explores empirically the impact of the changes in the economic environment on investment patterns at the firm level. Firm-level data allows exploitation of cross-sectional differences to make more robust inferences, avoiding the pitfalls of time series analysis using aggregate data stemming from the limited number of observations and the structural breaks generated by the crisis. The analysis attempts to assess more formally the impact of the relative price changes - specifically the real exchange rate and firms' costs of external borrowing —on investment. The latter aspect is captured through the construction of a firmspecific cost of capital variable (an effective interest rate derived from balance sheet data on debt and interest payments), a new approach in relation to recent papers in this area. ${ }^{8}$ Finally, this framework also allows for inference concerning the presence of financing constraints.

\section{A. Estimating Investment Equations in the Presence of Financial Constraints}

Drawing from the investment literature, the firm chooses the capital stock that maximizes the expected marginal productivity of capital subject to the constraints imposed by the production technology and the costs of installing new capital. Under perfect capital markets, the firms' financial structure would not matter to the investment decision, and in effect the firm could borrow all the funds required to optimize its capital stock at the prevailing market rate (as in Modigliani and Miller (1958)).

\footnotetext{
${ }^{8}$ The author is not aware of other papers including a similarly constructed variable. Recent papers on financing constraints in Argentina (aspects of which are discussed below) include Elosegui et. al. (2006), Sánchez and Butler (2007) and Fanelli et. al. (2003).
} 
However, in the presence of financing constraints, this is no longer the case. ${ }^{9}$ In such an environment, firms with high net worth will be more creditworthy, and changes in firms' net worth will affect their access to finance from outside the firm (henceforth "external finance"). ${ }^{10}$ This approach suggests, therefore, that the existence of financial constraints can be inferred if the firm's investment decision can be shown to be a function not just of fundamental opportunities (i.e. the expected marginal productivity of capital), but also of balance sheet characteristics speaking to its net worth or liquidity position.

Therefore, evidence of financial constraints is usually judged by finding strong correlations of investment with measures of internal funds - typically cash flow in standard accelerator or Tobin's q specifications. ${ }^{11}$ Higher cash flows today improve the financial position of the firm and increase internal funds for investment.

One important problem with this measure is that cash flow is also likely to contain information about the future profitability of investments, and thus be correlated with investment for fundamental reasons other than constrained access to external funds. This may particularly be the case in the presence of the capital market imperfections the variable is supposed to detect, where cash flow may be one of the few relatively reliable facts with information about the productivity of capital available to external investors.

In response to this problem, most studies use additional information on the firms in the sample to sort them into groups that can be supposed to face differing levels of access to market finance, typically firm size, existence of a bond rating or outstanding commercial paper issues, or dividend payout ratios. Evidence of financing constraints can be inferred only if the sensitivity of investment to cash flow is higher for those firms that can be a priori expected to be more financially constrained. ${ }^{12}$

\footnotetext{
${ }^{9}$ See Bernanke and Gertler (1989, 1990), Bernanke (2007) and Stiglitz and Weiss (1987).

${ }^{10}$ In the financial accelerator model, procyclical movements in firms' net worth — asset prices or investor optimism may run high in upswings or as a result of positive productivity shocks, for example-lead to changes in "external finance premiums" that generate the additional volatility observed in aggregate investment.

${ }^{11}$ There is by now a long tradition of using this or similar approaches. Fazzari et al. (1988) is a benchmark study for the US, while, for example, Bond et al. (1997) apply a similar approach for some European developed economies, and Galindo and Schiantarelli (2003) collects a series of studies for Latin American countries, including Fanelli et al (2003) for Argentina.

${ }^{12}$ Most papers in this literature discuss whether cash flow is a good proxy, though there are few plausible substitutes. For summaries covering this issue see Hubbard (1998), and Gilchrist and Himmelberg (1995, 1998). The latter authors propose a method for circumventing the issue within this basic strand of the literature. Other approaches include estimating Euler equations (e.g. Forbes (2007), but this has been regarded as problematic in other studies (e.g. Gelos and Werner (2002)), or structural VARs (see Love and Zicchino (2006)).
} 
Further, several studies have used the stock of cash rather than cash flow. ${ }^{13}$ This is intuitively appealing in that while financially-constrained firms might be expected to accumulate cash stocks to smooth investment (admittedly they may also do so for other reasons), it is not obvious that the stock of cash on a firm's balance sheet should be a good predictor of the expected returns on additional units of capital. In this study, a subset of small firms are identified, and the stock of cash is used. A significant coefficient on the interaction term for cash stock and small firms is sought to confirm the existence of financing constraints.

\section{B. Data}

The data are an unbalanced panel of 87 non-financial firms for the period 1993 to 2006 (see Annex 1 for details). The dataset includes only listed firms, introducing important caveats in drawing conclusions for the wider economy. These firms by definition have some access to external finance, and are all "large" by Argentine standards. Many of the companies included are part of international groups, which may give them greater access to finance through intrafirm or international capital market operations. Finally, a much greater proportion are involved in tradable sectors than in the economy as a whole.

Firms are categorized into "small" and "large" groups, and by whether they are in the traded or non-traded sectors. Two criteria were used to define firm size in the sample: first, firms were ranked by assets and year, with those in the highest and lowest quartiles defined as large and small respectively, for each year (i.e., the group composition changes by year). A second definition of small firms maintains the composition of this group constant, selecting firms ranked in the lowest quartile by assets in at least 9 of the 13 years of the sample, plus three firms with shorter lives that were ranked as small in all or all-but-one year of their lives. Empirical results did not vary significantly for the two definitions (overlap is high). Through the sample, 67 percent of firms ( 71 percent of observations) are in the traded goods sector, i.e. mining, agriculture or manufacturing, with a preponderance in manufacturing ( 58 percent of firms and 61 percent of observations).

Annex Table 1 presents median values for the variables derived from the balance sheet. An overview of this data is suggestive in two dimensions: smaller firms do not in fact seem to face worse financing constraints in this sample, and tradable sector firms have done much better in the post-crisis period. A third observation pertaining to the estimations might be made, which is that while there appears to be a clear change in investment behavior from the pre- to the post-crisis period, the other variables appear to be far more stable, and may therefore have relatively low overall explanatory power. It can be noted that the evidence is not inconsistent with the hypothesis of some analysts that the post-crisis environment favored the growth of small firms in the tradable sector, using labor-intensive production techniques.

\footnotetext{
${ }^{13}$ See, for example, Forbes (2007), Fanelli et.al. (2003) or Castañeda (2003).
} 
However, this question is not addressed in this paper as balance sheet data for small firms was not available to the author.

Looking in greater detail, the median investment capital ratio declined steadily from the commencement of the recession in 1998, and remained well below its values in the 1990s even at the end of the sample. As aggregate investment was rising in this period, this suggests that large, publicly-listed firms were either not the main beneficiaries of the post-crisis environment or grew using existing capacity. Even within the sample, the gap in investment between small and large firms narrowed notably, as investment of the largest firms fell substantially more than that of the smaller ones. Regarding the sector of operation, firms with both traded and non-traded outputs invested less after the crisis, with the fall being twice as large for firms in the non-traded sector.

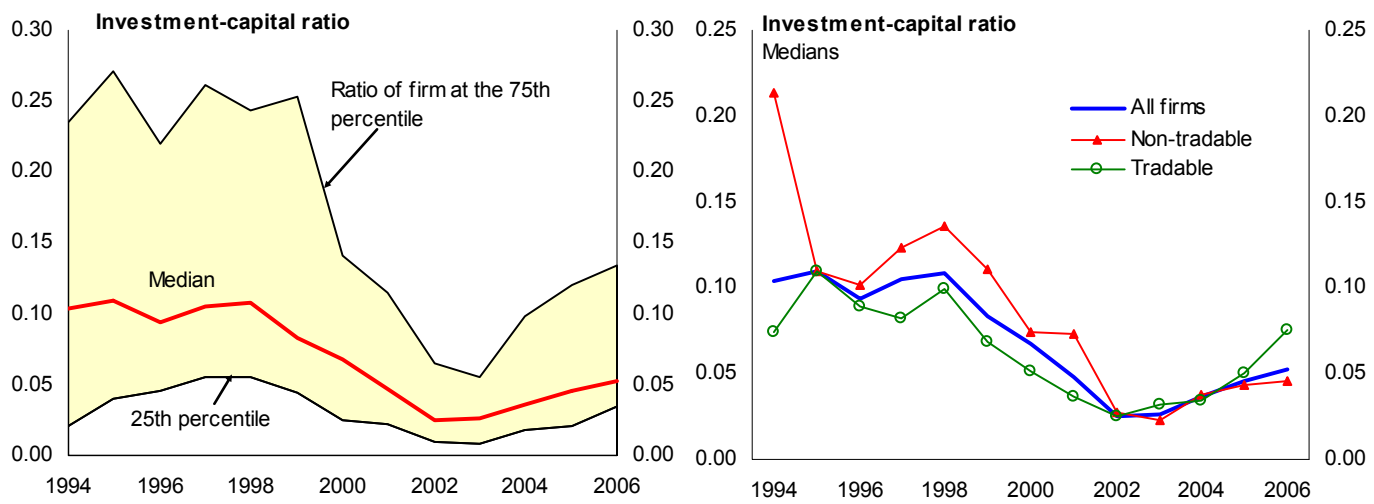

A pattern of improving circumstances for the smaller firms can also be detected in the sales data. During the pre-crisis period, the sales of the median small firm were shrinking; in the post-crisis period, sales growth in relation to capital exceeds that of the larger firms fivefold (although the median for small firms is much more volatile). Likewise, a significant improvement is detectable for firms in the traded goods sector. These firms suffered considerably more than firms with non-traded outputs in the 1998-2001 recession (a period of substantial peso overvaluation), but have had considerably more dynamic sales in the postcrisis period.

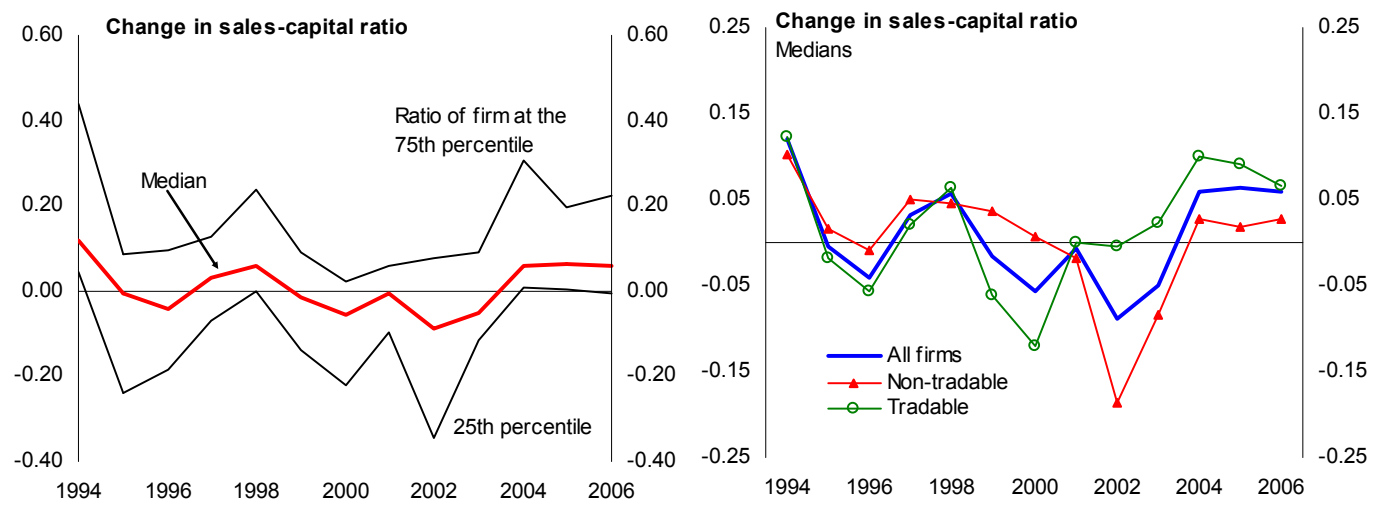


With regard to reserves of cash and near-cash, the overall increase in holdings after 2002 is consistent with more constrained access to external financial resources and the collapse of the banking system. Debt fell modestly compared to the pre-crisis period (the median debtasset ratio fell from 24.4 to 22.6 percent). However, the striking increase in large firms' holdings of cash is not evident for the smaller firms - in fact these remain roughly constant and fall below those of the large firms. The finding suggests that the larger firms may have felt any intensification of financing constraints more acutely than smaller firms, and built up cash positions accordingly. It should be noted, however, that the medians are volatile for both large and small firms. There is no substantial change in cash holdings across tradable/nontradable sectors of operation.

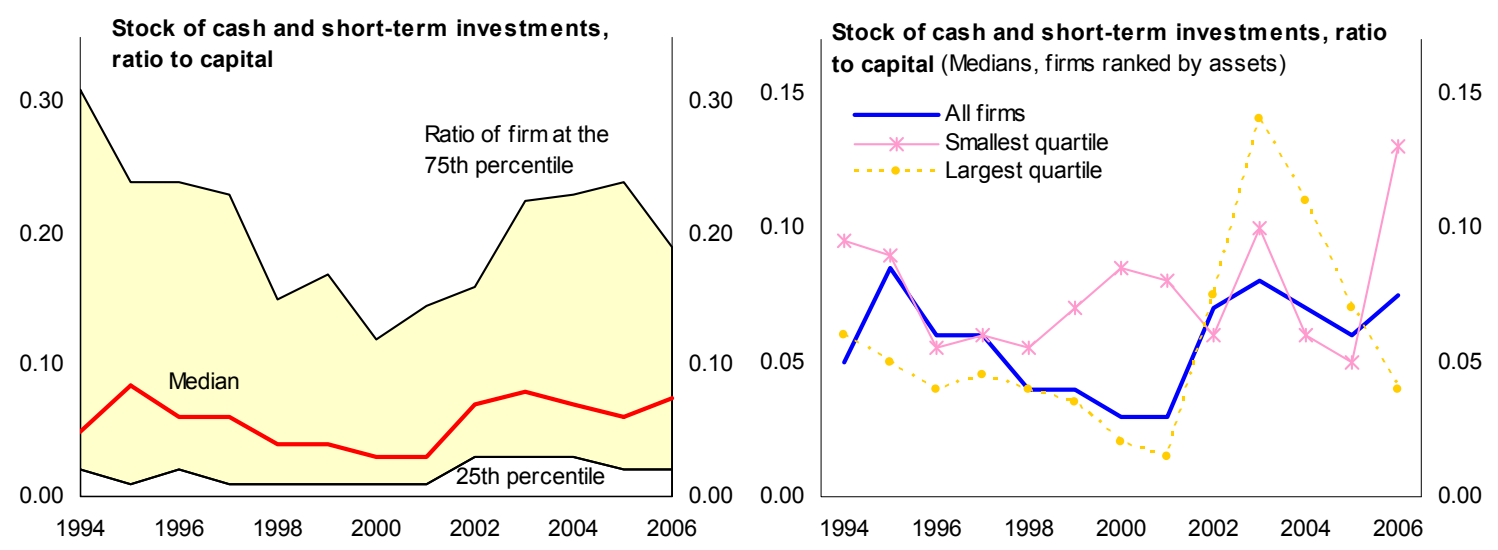

The effective interest rates paid by firms fell in the post-crisis period. The decline, however, is modest compared to the decline in benchmark rates. In fact access to external credit may have been limited by rationing rather than price. Smaller firms faced higher effective interest rates than larger firms in both periods. There was a reversal in the relative cost of debt for producers of traded and non-traded outputs - the former paid more than the latter prior to 2002 , and less subsequently, although the difference is small.

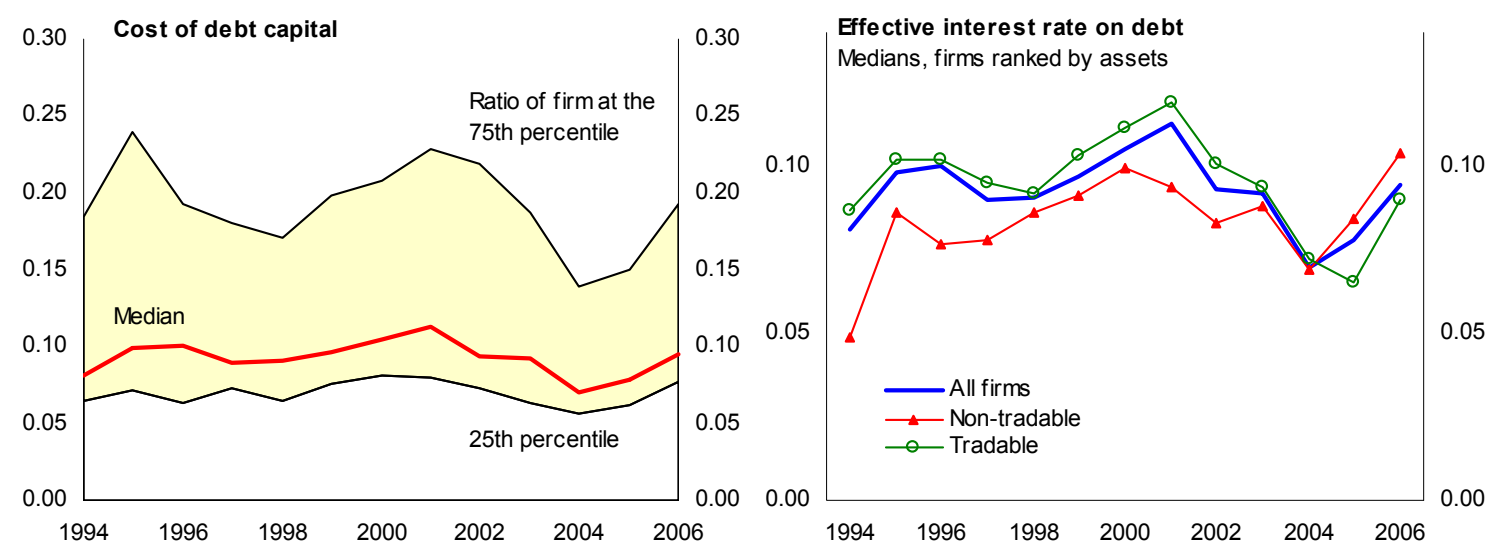




\section{Empirical Strategy}

This study follows the accelerator model approach, where investment is explained by the change in sales, and the stock of cash is included to capture the possibility of financing constraints, yielding the following equation:

$\frac{I_{i t}}{K_{i t-1}}=\beta_{1} \frac{\Delta S_{i t}}{K_{i t-1}}+\beta_{2} \frac{C_{i t}}{K_{i t-1}}+v_{i}+\varepsilon_{i t}$

Where $I_{i t}, K_{i t}, \Delta S_{i t}$, and $C_{i t}$, denote investment, capital stock, change in sales, and the stock of cash. $v_{i}$ is a variable capturing firm-specific heterogeneity not otherwise modeled, and $\varepsilon_{i t}$ is an idiosyncratic error term. Investment is measured using capital expenditures from the cash flow statement, with sales and the stock of cash and short-term investments also using data from financial statements. The capital stock is derived using a permanent inventory approach, (which accounts for depreciation). As discussed, in order to conclude that financing constraints exist, additional information must be brought to bear, and the cash term is interacted with dummies capturing firm size.

$$
\frac{I_{i t}}{K_{i t-1}}=\beta_{1} \frac{\Delta S_{i t}}{K_{i t-1}}+\beta_{2} \frac{C_{i t}}{K_{i t-1}}+\beta_{3} D U M(\text { Small }) * \frac{C_{i t}}{K_{i t-1}}+v_{i}+\varepsilon_{i t}
$$

In addition, the effect of two variables of interest are explored: the real exchange rate and an interaction term of this with firms producing tradable output, and an explicit variable for interest rates, constructed as a firm-specific cost of debt. The former is a CPI-based, effective rate and the latter an effective rate constructed from debt and interest payments data from financial statements. ${ }^{14}$ Unfortunately, the dataset does not include variables allowing analysis of the different channels through which the real exchange rate might affect investment (exported outputs, imported inputs and debt dollarization).

$$
\begin{aligned}
& \frac{I_{i t}}{K_{i t-1}}=\beta_{1} \frac{\Delta S_{i t}}{K_{i t-1}}+\beta_{2} \frac{C_{i t}}{K_{i t-1}}+\beta_{3} \log R E E R+\beta_{4} D U M(\text { Tradable }) * \log R E E R+v_{i}+\varepsilon_{i t} \\
& \frac{I_{i t}}{K_{i t-1}}=\beta_{1} \frac{\Delta S_{i t}}{K_{i t-1}}+\beta_{2} \frac{C_{i t}}{K_{i t-1}}+\beta_{3}(\operatorname{Cos} t K)+v_{i}+\varepsilon_{i t}
\end{aligned}
$$

The coefficient on sales is expected to be positive; returns on additional units of capital are likely to be positive for firms generating significant sales per existing unit of capital. The coefficient on the stock of cash is also expected to be positive. This could reflect both the existence of financial constraints, and the possible correlation of this variable with expected

\footnotetext{
${ }^{14}$ See Annex 1 for more details on all variables, and treatment of outliers.
} 
profitability, and a positive coefficient on the interaction term with small firm size is required to conclude the former hypothesis is valid. The coefficient on the cost of borrowing variable is expected to be negative, and the coefficient on the real exchange rate is indeterminate. We would, however, expect real exchange rate depreciation to favor investment in firms producing traded goods.

Finally, interaction dummies for the post-2001 period were used to assess whether the influence of any of the variables on the investment process changed significantly.

\section{Specification Problems and Endogeneity}

Several econometric issues arise in applying this framework. As noted, one issue in the financing constraints literature has been the suitability of cash flow as a measure of such constraints given its likely correlation with the marginal productivity of capital. Here, in addition to assessing differences across firm size, the stock of cash is used rather than the flow. As this variable's connection to the marginal productivity of capital is more tenuous, this should permit a clearer inference on the existence of financing constraints.

Another problem is presented by the probable simultaneous determination of investment, cash, and sales. Such an endogenous data determination process would render standard panel data estimators biased and inconsistent. It could be argued that sales might be predetermined (i.e. previous - but not current - investments would be correlated with the current levels of sales) - but this would still not meet the strict exogeneity condition for validity of fixed effects estimation. Again, the stock - as opposed to the flow - of cash might more reasonably be expected to be determined independently of the level of investment. Mulkay, Hall and Mairesse (2000) argue that the bias for their sample (covering twelve years, as opposed to thirteen here) will anyway be small, but this argument may be too sanguine for this dataset which includes a smaller number of cross-sectional units and is highly unbalanced.

While an instrumental variables approach might be appropriate, good proxies for cash flows or stocks from the financial statements are not likely to be uncorrelated with the dependent variable. Exogenous macroeconomic variables do not make ideal instruments as all crosssectional variation is lost. Nonetheless GDP growth, corporate tax and VAT receipts and various commodity price indices - likely to be correlated with corporate cash flow-were tried, with the results used as a cross-check on the basic findings.

A further likely possibility is that investment is determined through a dynamic process, with adjustment costs or serially correlated shocks (typically thought of as productivity shocks) leading to persistence in the dependent variable. A plausible case might also be made that investment decisions will be made on the basis of several years' realizations of profits, and accumulated cash flows. Inclusion of lags of the dependent and explanatory variables would violate the strict exogeneity assumption, however. As in many other recent studies, system GMM estimators designed to address this problem using internal instruments were used with a dynamic model specification (see Annex 2 for more details). this approach to be valid, 
however, several assumptions are important, including one that is violated in this dataset (namely absence of structural breaks that could affect any part of the sample). Finally, recursive estimation was tried, limiting the sample to 1993-2001 and progressively adding a years-worth of data to assess parameter stability.

\section{E. Results}

Results for fixed effects (FE) estimations are shown in Table $3 .{ }^{15}$ The change in sales and the cash stock variables are signed as expected, significant and of similar magnitude across most specifications (with and without interaction variables for small firms within the sample, and the real exchange rate and interest rate variables of interest). The exception is for the cash variable, which while preserving sign and magnitude, becomes insignificant when time dummies and the firm-specific cost of capital variable are included (Equations 4 and 5 on Table 3; see below). While R-squared statistics are low, the variables are always highly jointly significant.

In terms of magnitudes, the results suggest that the investment-capital ratio will rise by between 0.02 and 0.03 percentage points for each percentage point increase in the ratio of the change in sales to capital, and between 0.05 and 0.08 percentage points for each point increase in the cash stock to capital ratio. In these basic equations, an interactive dummy term on the cash variable for the smaller firms was positive, but not significant.

In the estimations most comparable to these, Elosegui et al. (2006) find results that are qualitatively similar in terms of significance, and quantitatively so for the sales variables. The coefficient on cash flow is much larger (by as much as ten times) than the coefficient on the stock of cash used here to capture financing constraints. ${ }^{16}$ Sánchez and Butler (2007) also find significant explanatory power for sales and cash flow-again, the sales variable has a similar to magnitude to that found here. However, the cash flow is found to have a negative impact on investment in the equations most similar to those presented here. Finally, Fanelli et. al. (2003), for an exclusively pre-crisis sample, find a (usually) significant role for cash flow about five times as large that found here. These authors use a Tobin's $q$ approach, do not include sales, but do include a lag of the dependent variable in their specifications.

\footnotetext{
${ }^{15}$ Using random effects yields similar results (although the cash flow variable is not significant at conventional levels). While a Hausman test cannot reject the null hypothesis of non-systematic differences between the two estimators, there are strong reasons to suppose firm-level fixed effects are important.

${ }^{16}$ These authors adopt a Tobin's $q$ approach, using cash flow and the growth rate in sales-i.e. there are still substantial differences with the variables used here. The Tobin's $q$ variable is rarely significant.
} 
Table 2. Results from Analytical Equations

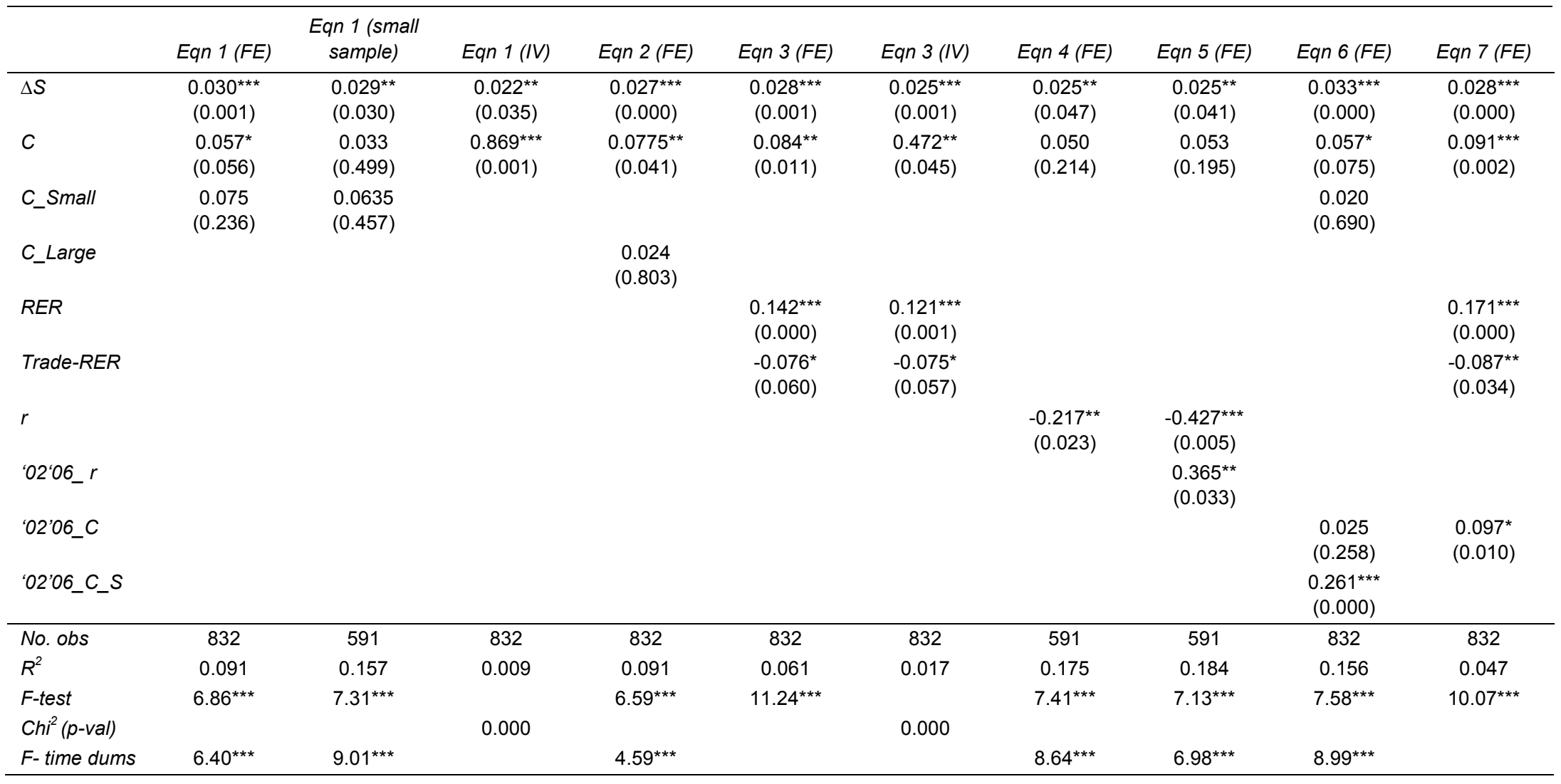

All equations estimated with robust standard errors. Instruments used for cash in the IV equations are non-fuel commodity prices and agricultural commodity prices (significant at 5 percent or better in first stage equations). Constants not reported.

${ }^{*},{ }^{* *}$, and ${ }^{* * *}$ indicate significance at 10,5 and 1 percent. P-values reported in parentheses.

$\Delta S$ is change in sales, $C$ the stock of cash and short-term investments, $C$ Small an interactive dummy of $C$ with firms in the lowest quartile of the sample, ordered by assets, for each year and $C$-Large the same for the firms in the largest quartile, $R E R$ the log of the real exchange rate, Trade-RER an interactive dummy of $R E R$ with firms producing traded outputs, $r$ the firm-specific cost of borrowing, '02'06_ $r$ an interactive dummy for $r$ with value zero prior to 2002, '02'06_C similar for cash, and '02'06_C_S for cash and small firm size. F- time dums is an F statistic for the joint significance of the time dummies, where included. 


\section{The real exchange rate}

Including the real effective exchange rate in the FE estimations always generated highly significant, positive coefficients. Including an interactive term of the real exchange rate with a dummy of whether the firm operates in the traded goods sector yields negatively-signed, significant coefficients. The results are robust to changes in specification, and hold in the IV estimation (Table 3, Equation 3). ${ }^{17}$

These results show that a one percent increase in the real exchange rate (i.e., an appreciation) is correlated with an increase in the investment-capital ratio of about 0.15 percentage points. This suggests that increased affordability of imported inputs and greater ability to service dollar-denominated debt outweigh the lower peso value of exports in the investment decision. For traded goods sector firms whose output is priced internationally, however, the beneficial impact of an appreciation is reduced by about half, an intuitive result. The results are also consistent with the qualitative evidence for the 500 largest firms presented in the first part of the paper (a decline in overall investment, with a reversal in the previous pattern with traded goods firms investing more than non-traded after the devaluation).

\section{The effective interest rate}

Including the cost of debt variable significantly restricts the sample size (by almost 30 percent - see Annex 1), and these results are therefore not directly comparable with the others presented. For purposes of comparison, the basic specification was run on the reduced sample (Table 3, equation 1 "small sample"); the change in sales is similarly signed, significant and of similar magnitude as in the full sample. The cash variable is also of similar sign and magnitude, but becomes insignificant at standard significance levels - and remains so when the cost of capital variable is added (Table 3, equations 4 and 5). While this finding suggests care in interpreting the results, it is perhaps not surprising given the large reduction in sample size and comfort is drawn from the stability of signs and magnitudes of the coefficients.

Interpreting the coefficients, increases in the effective cost of borrowing have a negative effect on investment, with the investment capital ratio falling by about 0.2 of a percentage point for each percentage point increase in the effective interest rate. Including an interactive term for the cost of capital in the post-crisis period increases the magnitude and significance of the term for the whole period, while the coefficient on the interaction term is positive and

\footnotetext{
${ }^{17}$ Separating tradable firms into "manufacturing" and "others" (mining, oil and agriculture, representing eight firms and 85 observations) does not alter the sign or significance of the coefficients, or materially affect magnitudes, in either fixed effects or instrumental variables estimations (results not reported). The coefficient on the interactive term for manufacturing firms retains the magnitude and significance of that for all tradable firms, while the coefficient on the interactive term for other tradable firms was not significantly different from zero. A test of equality between coefficients for the two sub-groups could not be rejected.
} 
significant, yielding a weaker total effect for the post-crisis period than for the whole sample. This suggests that the interest rate sensitivity of investment declined after 2002, which may reflect greater rationing of external finance (i.e. with less external financing available overall, firms were willing to take what was available with less regard to its cost).

\section{Financing constraints}

For a clear conclusion that the econometric evidence shows the presence of financing constraints, the coefficient on the interactive term for small firms with cash must be positive and significant. However, across specifications, this term is positive but insignificant (the result holds using both of the definitions of "small" detailed in section B above-Table 3 shows results for the first definition of small). Using a dummy for firms in the largest quartile of the sample yields similar results (Table 3, equation 2), suggesting either that the firms are not sufficiently differentiated on this criterion (i.e., they are all treated as "large" by Argentine lenders), or perhaps that medium-sized firms that face the most acute constraints. Elosegui et. al. (2006) report a similar result.

However, as noted, the fall in bank credit after the crisis and the suspension of foreign financing suggest there is a strong prima facie case for supposing financing constraints became more acute after 2002 until 2006. Including interaction terms for the post-crisis period with the cash and cash-small firms variables provides some confirmation (Table 3, equation 6). The coefficient on the interaction term for cash and small size remains insignificant, as is the term interacting cash holdings with the post crisis period. However, the coefficient on cash holdings for small firms in the post crisis period is positive and highly significant (this holds for both definitions of small firms). Including the real exchange rate (equation 7) yields a positive and significant coefficient for the interactive term on cash holdings in the post-crisis. Given the strong prior supposition, this finding suggests the evidence is not inconsistent with a significant worsening of financing constraints in the postcrisis period.

\section{F. Dealing with Specification Problems}

Including time dummies for each year did not substantially alter the results. Dummies for years 2001 on are significant, and they are jointly significant. Time dummies were included in all estimations except those including the real exchange rate variable (as this variable is the same for all firms in the sample, it is exactly colinear with the combined time dummies, and would be dropped in estimation). Coefficient estimates on the time dummies are not reported on Table 3, though F-statistics for joint significance are.

\section{Instrumental variables}

Instrumental variables (IV) estimation was tried to account for the possibility of endogenous determination of the dependent variable and the cash variable. Instruments tried included GDP growth, various commodities price indices, and corporate tax and VAT receipts. The 
results are qualitatively similar to the baseline equation (Table 3, Equations 1 (IV) and 3 (IV)) — coefficients on sales and (instrumented) cash are signed similarly and significantand robust to progressive elimination of insignificant instruments. F and Chi-squared tests show strong joint significance, although R-squareds are lower than the baseline estimation. While the coefficient on the change in sales retains the same magnitude as in the FE estimations, the instrument for cash is several times larger that in the FE estimation. Overall, these results suggest that even if endogeneity is a problem, biases in the FE equation may not be large. While the broad interpretation of the results does not change, the change in magnitude of the coefficient estimates suggests some caution is warranted.

\section{System GMM}

As noted, investment is likely to be a dynamic process, in which case the static FE specifications would miss important information, while introducing lags would bias the results. In order to address this, at least to the extent that the dynamic element in the process is caused by adjustment costs in investment, system GMM estimations were tried. This approach in very intensive in instruments (found internally in the data set), and assumes stability in the data generating process. Given the crisis occurring in the middle of the sample, and the unbalanced nature of the panel, results must be treated with caution (see Annex 2 for a fuller discussion and a table of results). With this caveat, the results suggest that a dynamic specification is appropriate, with positive and significant coefficients on the

first and second lag of the dependent variable (Elosegui et. al. (2006) do not find conclusive evidence, however). The results also suggest the basic specification is reasonable - the coefficient on the sales variable is significant (the lags are not), similarly signed and only slightly larger than in the FE estimation. The coefficient on the cash variable is not significant, however, although signed as expected and larger than in the FE estimations.

Of themselves, however, the GMM results were generally not robust to inclusion of other variables, hinting at the effects of the instrument overidentification problem that this approach suffers from (it is noteworthy, however, that the first lag of the dependent variable and the sales variable are always signed as expected and significant). Hansen statistics of overidentifying restrictions were usually close to (some passing, some failing depending on the exact specification) the upper bound suggested by Roodman (2006), and coefficients for cash, cost of debt capital, or real exchange rate were volatile, mostly insignificant and sometimes changed signs depending on the exact specification.

\section{Recursive estimation}

In order to judge whether parameters remained stable despite the crisis, the basic equation was estimated recursively, starting with the subsample 1993-2001 and progressively adding one year. While for the shortest sample period the coefficient estimate on the stock of cash is not significant, coefficient estimates are otherwise always significant, with the appropriate signs, and the variables remain highly jointly significant. 

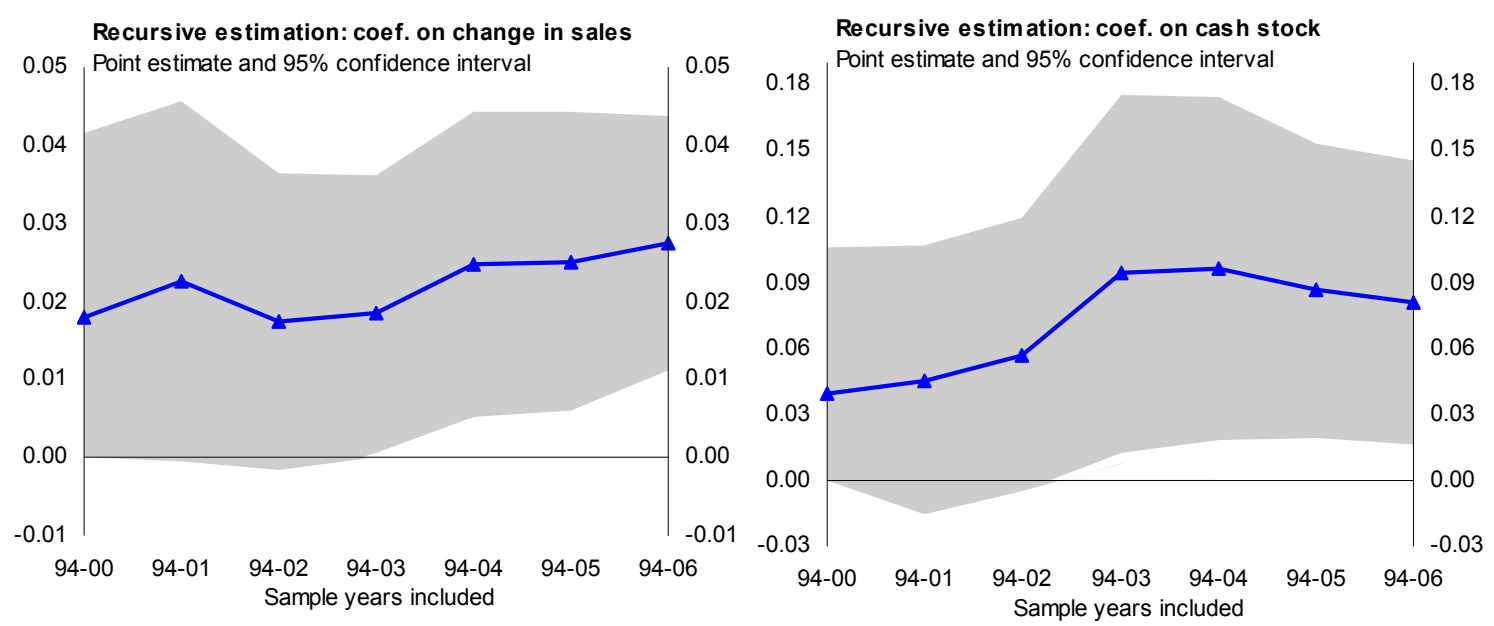

\section{Conclusions}

A qualitative review of the aggregate data suggests that the investment process in Argentina changed in the post-crisis period. Important relative price changes - in the real exchange rate, real interest rates, energy costs, the terms of trade and real wages - affected investment incentives and favored tradable and energy-intensive firms (essentially primary production and manufacturing) relative to their peers.

Aggregate investment in fact rose to levels exceeding those seen during the 1990s as the economy rapidly recovered. Data on the 500 largest firms shows that traded goods sectors were indeed more profitable than those in non-traded sectors after 2002. Despite the much lower real interest rate environment, aggregate credit fell substantially, indicating that financial constraints facing firms may have increased. Lower real wages also favored laborintensive activity, and capital per worker did not return to previous peaks in the sample period.

These qualitative assessments are broadly confirmed in the empirical analysis undertaken for 87 listed firms between 1993 and 2006. These firms are large by Argentine standards, enjoying access to capital markets, and this paper does not draw conclusions about the behavior of small and medium firms. An investment model linking investment with changes in sales and the stock of cash was augmented with information on the real exchange rate and the cost of capital, using a firm-specific effective interest rate measure. Interaction terms were used to assess differing impacts across firms in the traded and non-traded goods sectors, and for the smaller of the firms in the sample. The empirical work is subject to several methodological caveats, but the basic findings are generally robust across different specifications and estimation techniques.

For large firms, real exchange rate appreciation is correlated with higher investment, suggesting the benefits of cheaper imported inputs and greater ease of servicing dollardenominated debt could outweigh the benefits of higher returns from exports. However, this 
effect is only about half as large for firms with tradable outputs. This is consistent with the observed lower overall investment displayed by these firms, but with tradable sector firms investing relatively more. A corollary conclusion — given the rise in aggregate investmentis that firms not captured in this sample -particularly small and medium size enterprisesmust collectively have greatly increased investment.

Regarding financing conditions, as expected, investment declines in the effective interest rate paid on firms' debt. Overall debt has fallen modestly in the post-crisis period. There is some evidence that the interest rate sensitivity of investment decreased after the crisis, perhaps reflecting greater rationing of credit. While strong evidence of financing constraints is not found for the full sample period, perhaps reflecting insufficient variation in firm size across the sample, results are not inconsistent with financing constraints having worsened during the period 2002-2006. 
Figure 1. Relative Prices Before and After the Crisis

Period of convertibility shaded in grey
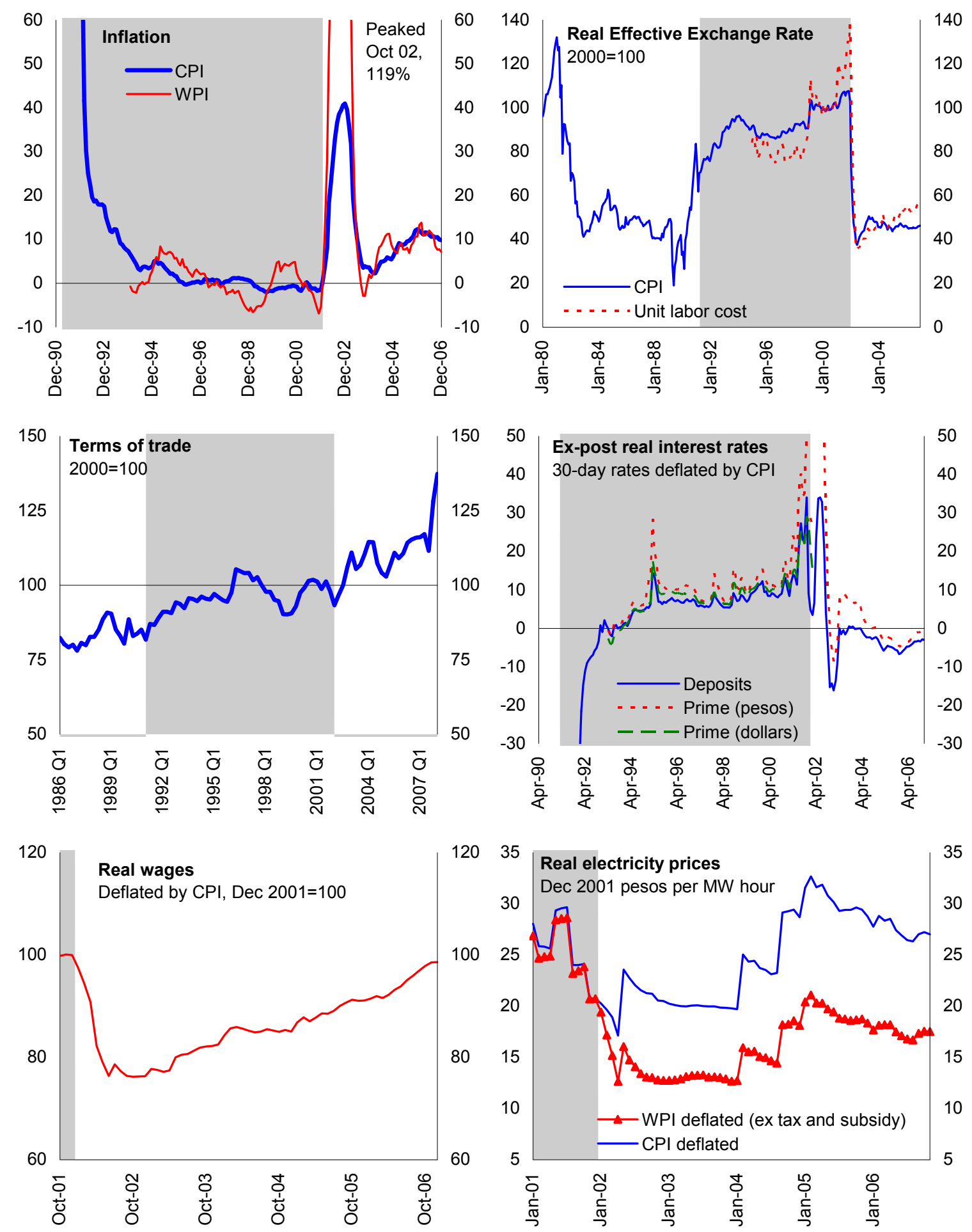

Source: INDEC, BCRA, CAMMESA and Fund staff calculations 
Figure 2. Savings and Investment
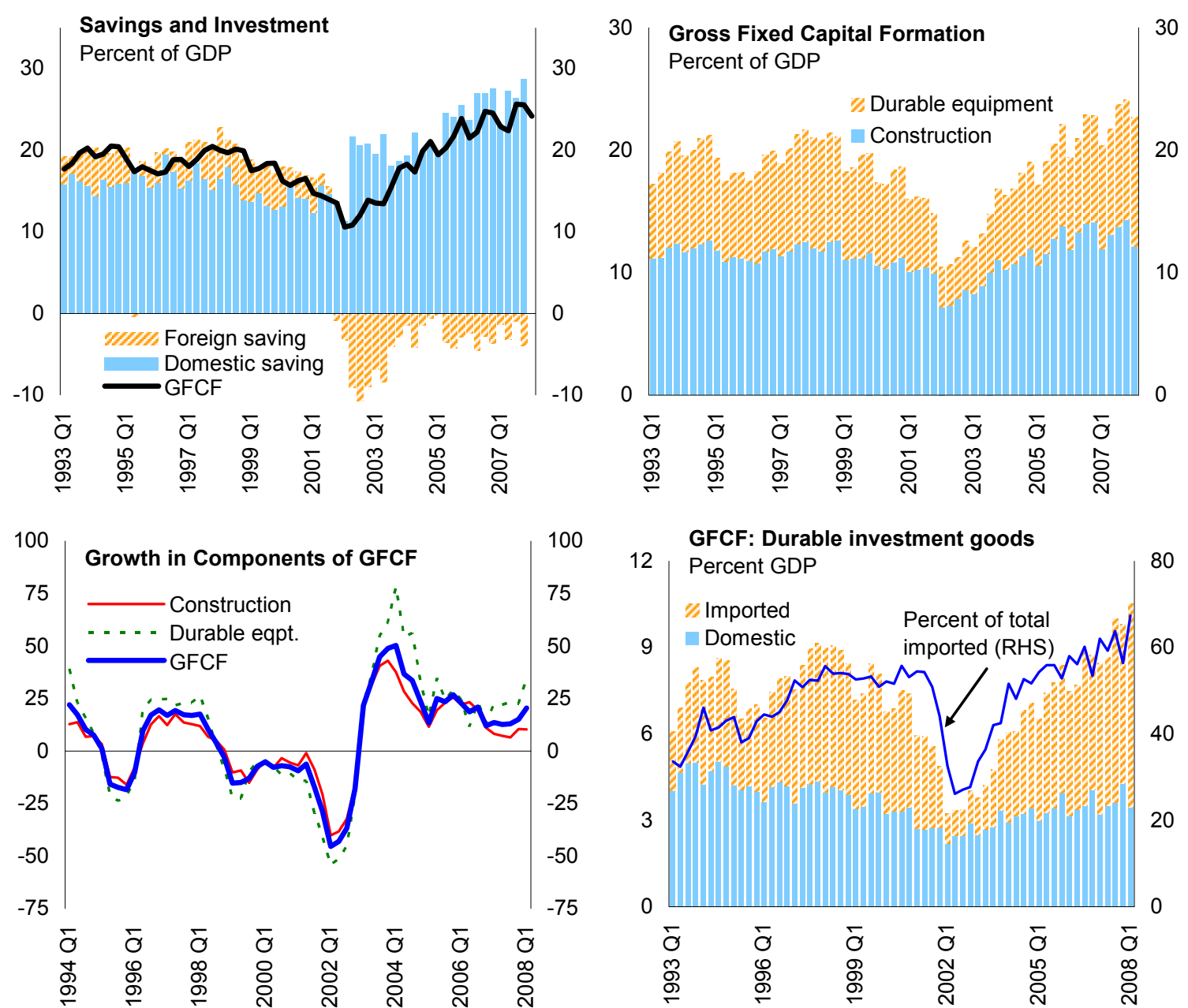

\section{GFCF: Durable investment goods}

\begin{tabular}{ll|l|l|}
75 & 12 & $\begin{array}{l}\text { Percent GDP } \\
\text { \%Imported }\end{array}$ & Percent of total
\end{tabular}

9 Domestic Percent of total

9 imported (RHS) 60

6

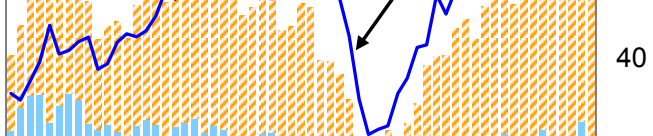

3

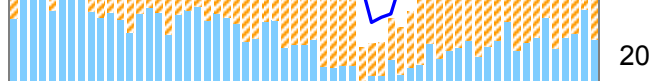

0

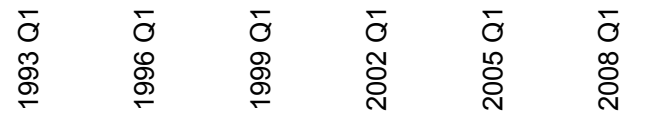
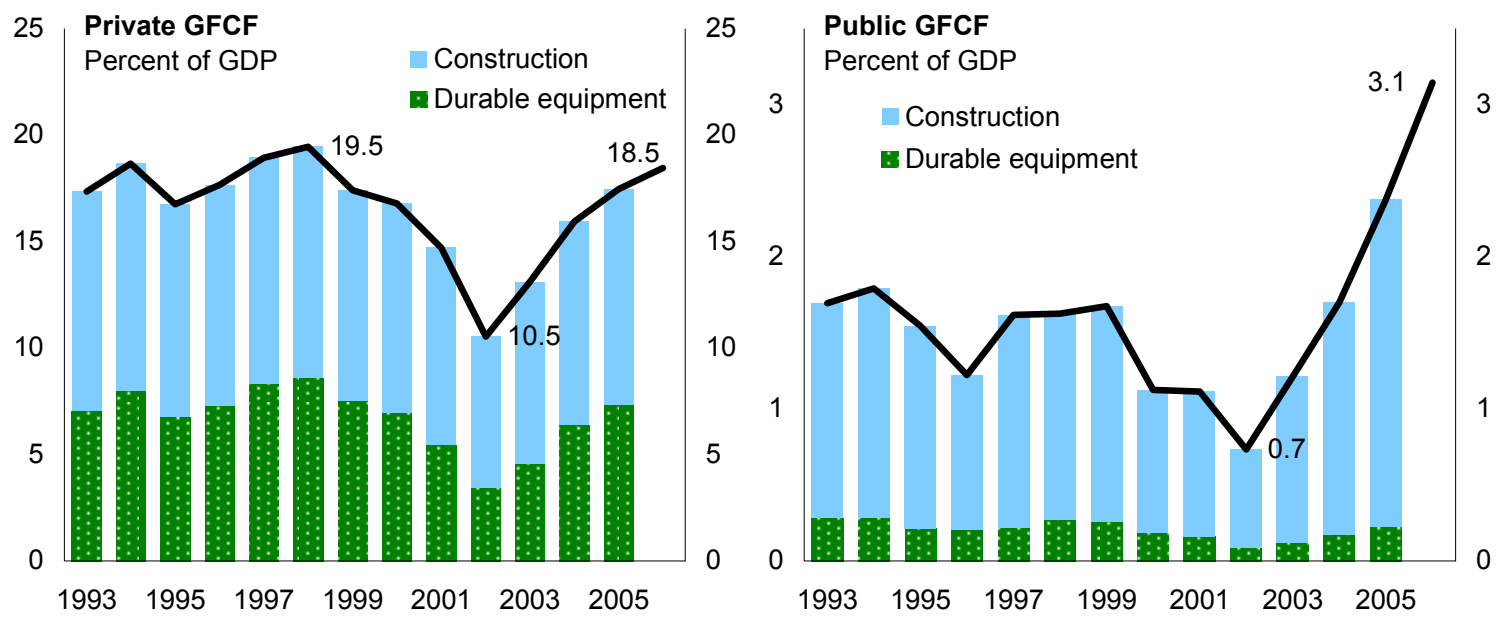

Source: INDEC 
Figure 3. Aggregate Investment: Regional Comparison 1/
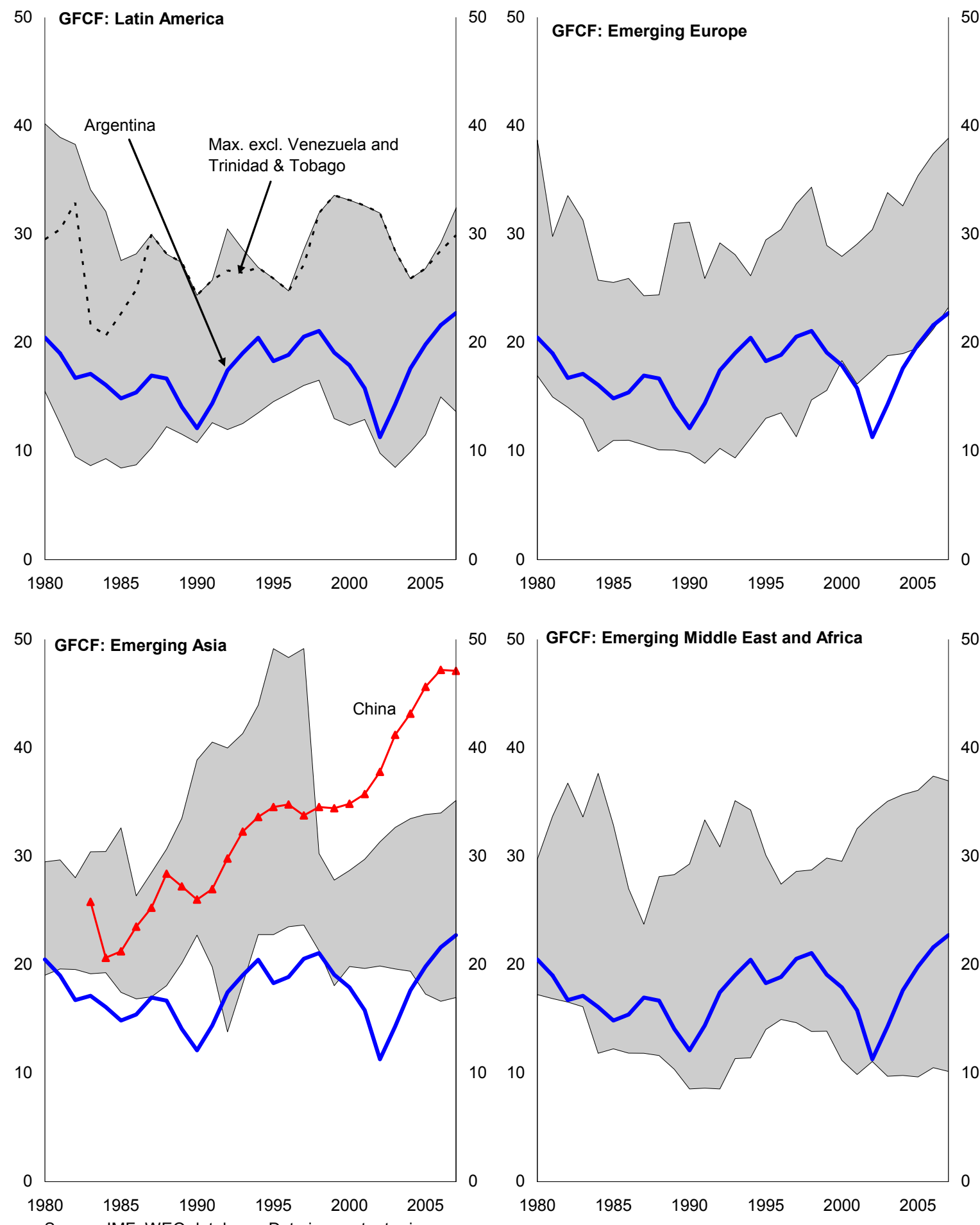

Source: IMF, WEO database. Data in constant prices.

1/ Latin America: Argentina, Bolivia, Brazil, Chile, Colombia, Costa Rica, Dominican Republic, Ecuador, Mexico, Paraguay, Peru, Trinidad \& Tobago, Uruguay and Venezuela. Emerging Europe: Bulgaria, Croatia, Czech Republic, Estonia, Hungary, Latvia, Lithuania, Poland, Romania, Slovak Republic, Turkey and Ukraine. Emerging Asia: China (mainland), India, Indonesia, Malaysia, Philippines, Thailand and Vietnam. Emerging Middle East and Africa: Egypt, Iran, Pakistan, Tunisia, Côte d'Ivoire, Nigeria and South Africa. 
Figure 4. Aggregate Returns to Capital and Labor
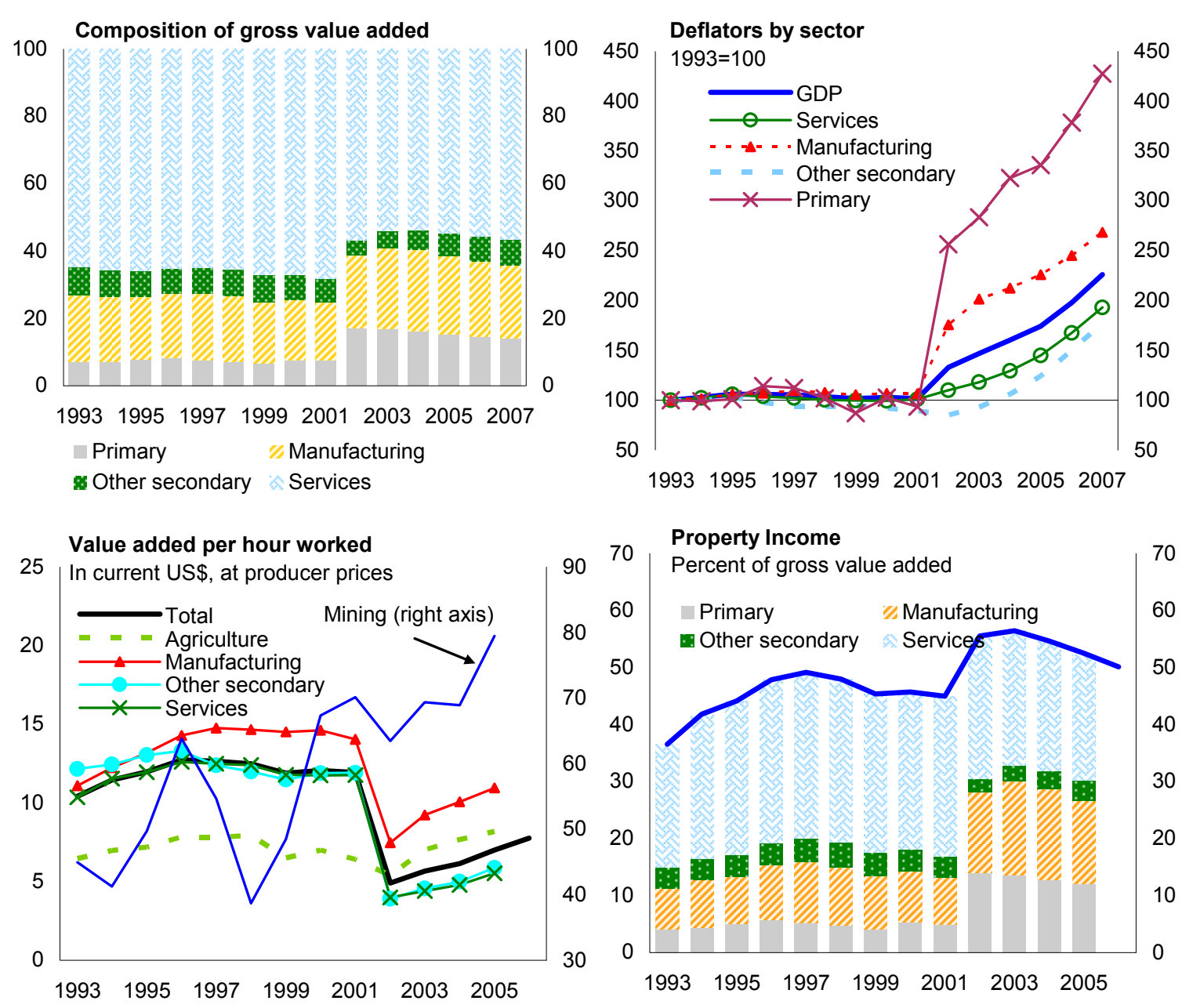

Labor cost per unit of value added



Aggregate Return on Capital

Ratio of property income to capital stock, percent $1 /$

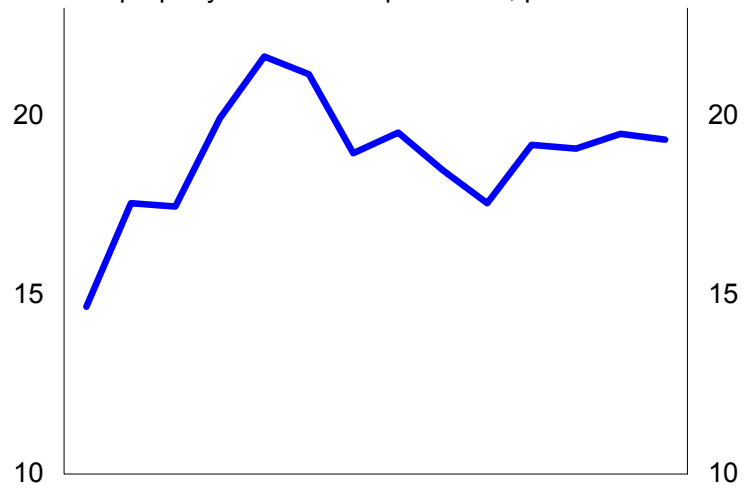

Source: INDEC

$\begin{array}{lllllll}1993 & 1995 & 1997 & 1999 & 2001 & 2003 & 2005\end{array}$

1/ Capital stock reflated with GFCF deflator. 
Figure 5. Investment of Large Firms
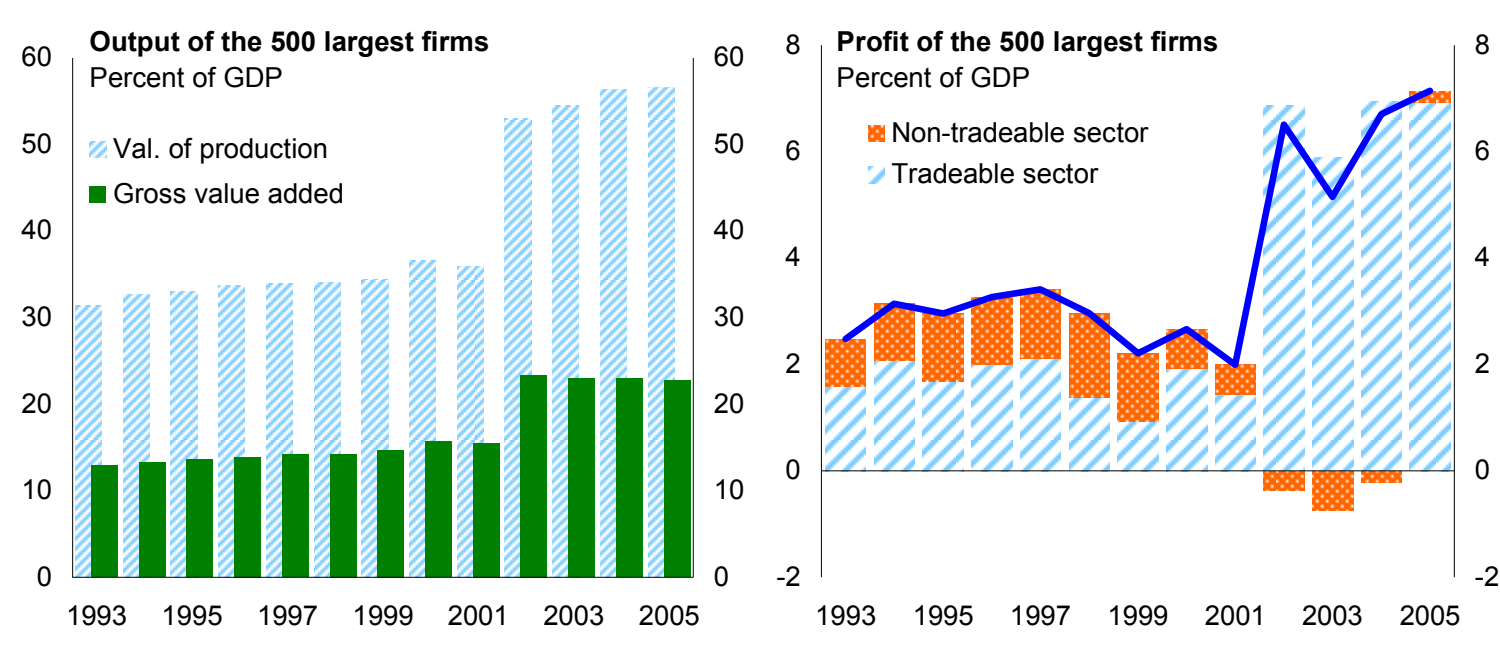

Profits and financial expenses
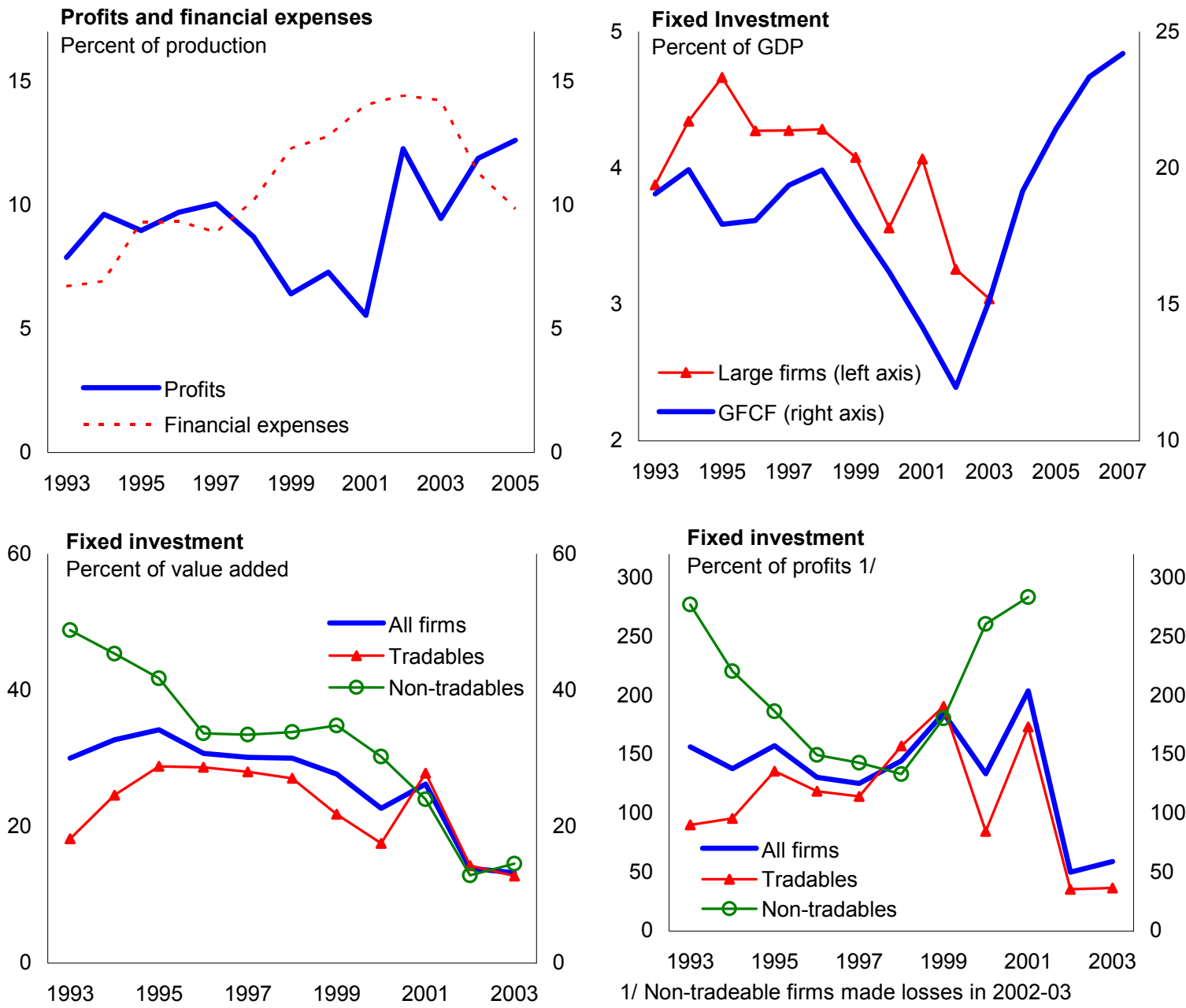

Source: INDEC (Encuesta Nacional de Grandes Empresas) 


\begin{abstract}
AnNeX 1. DAta
The data covers a sample of 87 non-financial firms listed on the Argentine stock exchange, from 1993 to 2006, drawing from financial statements. ${ }^{1}$ The sample is unbalanced, with relatively few firms existing at both the beginning and end of the sample, testimony to macroeconomic volatility during the sample period, as well as to the sale of argentine firms to foreign investors. There are also gaps in the data for some firms around 2002.

Investment, sales and the stock of cash and short term investments are derived from balance sheet information. The capital stock variable is derived through a permanent inventory approach, taking the initial capital stock as property plant and equipment at the earliest available date from the balance sheet, and assuming a depreciation rate of 8 percent. The investment and capital stock variables were deflated by an index of machinery and electrical equipment prices from the wholesale price index produced by the Argentine Institute of Statistics and Census (INDEC), while sales and cash flow were deflated by the overall WPI.

The real exchange rate variable is the log of a trade-weighted, CPI-based multilateral index calculated by Fund staff.
\end{abstract}

The cost of capital for each firm is the effective rate derived from debt and interest payment data from the financial statements. These data are the weakest in the sample, with many "illogical" or extreme values. After eliminating these data (all values less than zero or in excess of twice the contemporaneous prime lending rate were excluded) the number of observations in the sample is reduced by almost thirty percent-i.e. it is a substantively different sample. The problem arises from the 2002 crisis and the way it is reflected in debt and interest payment accounting data. Many firms restructured their debt in response to the crisis, and made provisions against anticipated or possible changes to debt service costs. Some of these provisions were later reversed - registering as negative interest payments on cash flow statements. There are also step changes in debt stock variables from one year to the next when restructurings are completed. The process of contract redenomination and renegotiation and the duration of the renegotiation period varied widely across firms, making a uniform treatment infeasible.

A second, much lesser source of outliers in the sample was concentrated at the terminal points of firms' lives. This results from very low and rapidly rising entries for property, plant fixed capital in the first year of a firms life (six observations dropped). Finally, three firms were dropped entirely due to insufficient or inconsistent data.

\footnotetext{
${ }^{1}$ The data for estimation was drawn from the Economatica database, and a database structure from an earlier Inter-American Development Bank (IDB) study. The author thanks Duong He and Emory Ventura at Economatica for their help, and access to the database during a trial period, and Herman Kamil, for help with the IDB database.
} 
Annex Table 1 shows median values for the variables derived from the financial statements used in the analysis. Values are shown for the pre and post-crisis periods, for small and large firms (by the first definition of "small" - see section II B), and by whether firms are in traded or non-traded sectors.

Annex Table 1. Descriptive Statistics for Firm-level Sample

\begin{tabular}{|c|c|c|c|c|c|c|c|c|}
\hline & \multicolumn{4}{|c|}{ Full sample (1994-2006) } & \multicolumn{2}{|c|}{ Pre-crisis (1994-2001) } & \multicolumn{2}{|c|}{ Post-crisis (2002-06) } \\
\hline & Obs & $25^{\text {th }}$ pcile & Median & $75^{t h}$ pcile & Obs & Median & Obs & Median \\
\hline$I / K$ & 847 & 0.02 & 0.06 & 0.13 & 499 & 0.08 & 348 & 0.04 \\
\hline Small & 208 & 0.01 & 0.04 & 0.08 & 123 & 0.05 & 85 & 0.02 \\
\hline Large & 212 & 0.04 & 0.09 & 0.15 & 126 & 0.11 & 86 & 0.04 \\
\hline Traded & 608 & 0.02 & 0.06 & 0.14 & 380 & 0.07 & 228 & 0.04 \\
\hline Non-traded & 239 & 0.03 & 0.06 & 0.12 & 119 & 0.10 & 120 & 0.04 \\
\hline$\Delta$ Sales/K & 832 & -0.10 & 0.02 & 0.13 & 491 & 0.01 & 341 & 0.02 \\
\hline Small & 196 & -0.26 & 0.01 & 0.21 & 116 & -0.04 & 80 & 0.05 \\
\hline Large & 212 & -0.06 & 0.01 & 0.09 & 126 & 0.02 & 86 & 0.01 \\
\hline Traded & 593 & -0.12 & 0.02 & 0.15 & 372 & 0.00 & 221 & 0.07 \\
\hline Non-traded & 239 & -0.07 & 0.01 & 0.09 & 119 & 0.02 & 120 & 0.00 \\
\hline Cash/K & 847 & 0.02 & 0.05 & 0.17 & 499 & 0.04 & 348 & 0.07 \\
\hline Small & 208 & 0.02 & 0.07 & 0.22 & 123 & 0.07 & 85 & 0.07 \\
\hline Large & 212 & 0.02 & 0.05 & 0.13 & 126 & 0.03 & 86 & 0.08 \\
\hline Traded & 608 & 0.01 & 0.06 & 0.19 & 380 & 0.05 & 228 & 0.07 \\
\hline Non-traded & 239 & 0.02 & 0.05 & 0.13 & 119 & 0.04 & 120 & 0.07 \\
\hline Cost of $K$ & 601 & 0.07 & 0.09 & 0.12 & 378 & 0.10 & 223 & 0.08 \\
\hline Small & 113 & 0.08 & 0.11 & 0.14 & 74 & 0.12 & 39 & 0.10 \\
\hline Large & 188 & 0.07 & 0.08 & 0.10 & 111 & 0.09 & 77 & 0.08 \\
\hline Traded & 410 & 0.07 & 0.10 & 0.13 & 273 & 0.10 & 137 & 0.08 \\
\hline Non-traded & 191 & 0.07 & 0.08 & 0.11 & 105 & 0.09 & 86 & 0.08 \\
\hline
\end{tabular}




\section{ANNEX 2. GMM ESTIMATIONS}

Designed for panels with relatively short time periods compared to cross-sectional units, system GMM handles the endogeneity arising from inclusion of lags by transforming the data. This approach can also be used in the presence of individual-specific heteroskedasticity and serial correlation in the errors, although idiosyncratic disturbances are assumed uncorrelated across individuals (usually prompting the inclusion of dummies for each sample year, as is done here). "System" GMM advances on two-stage least squares or "difference" GMM estimators by adding information on the levels of the variables to the transformed data, greatly improving the efficiency of the estimators. ${ }^{1}$ However, for the lagged, transformed series to be valid instruments, they must be uncorrelated with the individual fixed effects, adding a new assumption. This assumption can be thought of as implying that the cross sectional units are in a steady-state (in this case, the best analogy might be that each firm's investment strategy is stable through time). As the sample includes a major crisis generating a structural break, this assumption does not appear valid in this case. ${ }^{2}$

A problem with this technique is "overidentification" - as the number of instruments rises exponentially in the number of lags available, finite samples often lack sufficient information to estimate the moments well. Sargan-Hansen tests of the correlation of the instruments with the residuals also lose power as the instrument count rises, implying that the range of pvalues in which the instrument set can be considered valid is relatively narrow (Roodman (2006) suggests Hansen test p-values should lie 0.1 and 0.25). Here, Hansen tests are preferred as the structural break in the series implies errors are likely heteroskedastic.

Given that the sample contains gaps for some observations, differencing would magnify the loss of data implied by the transformation; instead, the data was transformed using forward orthogonal deviations (the average of all future available observations are subtracted from the contemporaneous observation). Two-step estimation was used (i.e. an arbitrary covariance matrix is assumed for the residuals in the first stage and the errors generated are then used to construct the matrix for the second stage estimation). In order to avoid possible small sample bias resulting in incorrect standard errors, the Windmeijer correction is applied. Finally, given the high instrument count relative to the number of cross-sectional units in the transformed data, additional results are reported for the "collapsed" instrument set."

\footnotetext{
${ }^{1}$ The "difference GMM" nomenclature is standard, although transformations other than differencing are possible, and used here. "System GMM" is designed to address the "weak instruments" problem that arises when first differences of persistent series yield data close to white noise offering little additional information.

${ }^{2}$ See Arellano and Bond (1991) and Arellano and Bover (1995). The estimation of was done in Stata, using the xtabond2 command developed by David Roodman (see Roodman 2006).

${ }^{3}$ For a full discussion of these options see Roodman (2006).
} 
Annex Table 2. System GMM Estimations

\begin{tabular}{|c|c|c|c|}
\hline & Eqn 1 & Eqn 2 & Eqn 3 \\
\hline Investment (L1) & $\begin{array}{c}0.241^{* * *} \\
(0.000)\end{array}$ & $\begin{array}{c}0.260^{* * *} \\
(0.000)\end{array}$ & $\begin{array}{r}0.260^{* * *} \\
(0.000)\end{array}$ \\
\hline I (L2) & $\begin{array}{c}0.058^{*} \\
(0.073)\end{array}$ & $\begin{array}{c}0.025 \\
(0.417)\end{array}$ & $\begin{array}{c}0.027 \\
(0.400)\end{array}$ \\
\hline Sales & $\begin{array}{l}0.039^{* *} \\
(0.050)\end{array}$ & $\begin{array}{l}0.025^{\star *} \\
(0.034)\end{array}$ & $\begin{array}{l}0.024^{*} \\
(0.056)\end{array}$ \\
\hline$\Delta \mathrm{S}(\mathrm{L} 1)$ & $\begin{array}{c}0.006 \\
(0.605)\end{array}$ & $\begin{array}{c}0.010 \\
(0.351)\end{array}$ & $\begin{array}{c}0.009 \\
(0.364)\end{array}$ \\
\hline$\Delta \mathrm{S}(\mathrm{L} 2)$ & $\begin{array}{l}0.0005 \\
(0.958)\end{array}$ & $\begin{array}{l}0.0008 \\
(0.935)\end{array}$ & $\begin{array}{l}-0.001 \\
(0.880)\end{array}$ \\
\hline Cash stock & $\begin{array}{c}0.128 \\
(0.448)\end{array}$ & $\begin{array}{l}-0.090 \\
(0.122)\end{array}$ & $\begin{array}{l}-0.101^{*} \\
(0.078)\end{array}$ \\
\hline$C(\mathrm{~L} 1)$ & $\begin{array}{c}0.000 \\
(0.999)\end{array}$ & $\begin{array}{c}0.062 \\
(0.268)\end{array}$ & $\begin{array}{c}0.061 \\
(0.293)\end{array}$ \\
\hline$C(\mathrm{~L} 2)$ & $\begin{array}{c}0.025 \\
(0.417)\end{array}$ & $\begin{array}{c}0.055 \\
(0.101)\end{array}$ & $\begin{array}{c}0.061 \\
(0.110)\end{array}$ \\
\hline Cash stock/ small firms & & $\begin{array}{c}0.070 \\
(0.364)\end{array}$ & $\begin{array}{c}0.076 \\
(0.309)\end{array}$ \\
\hline C_S (L1) & & $\begin{array}{l}-0.027 \\
(0.568)\end{array}$ & $\begin{array}{l}-0.025 \\
(0.611)\end{array}$ \\
\hline C_S (L2) & & $\begin{array}{c}-0.089^{* *} \\
(0.035)\end{array}$ & $\begin{array}{c}-0.087^{* *} \\
(0.033)\end{array}$ \\
\hline Log real exchange rate & & & $\begin{array}{l}-0.707 \\
(0.566)\end{array}$ \\
\hline $\mathrm{RER} /$ tradable firms & & & $\begin{array}{l}-0.019 \\
(0.242) \\
\end{array}$ \\
\hline No. of observations & 656 & 656 & 656 \\
\hline Instrument count & 47 & 59 & 60 \\
\hline Hansen p-value & 0.630 & 0.201 & 0.158 \\
\hline
\end{tabular}

Equations system-GMM results with the collapsed instrument matrix.

${ }^{*},{ }^{* *}$, and ${ }^{* * *}$ indicate significance at 10,5 and 1 percent. P-values reported in parentheses.

In the specification estimated, two lags of the dependent variable, sales, and cash stock were added to the level equation. Estimations including the cost of external borrowing were weaker, and are not reported. Lags of the real exchange rate were included as exogenous instruments, while lags of two and deeper for investment, sales and cash stock were included as "GMM-style" instruments (twice-lagged instruments are appropriate for endogenous variables, while a single lag will suffice for pre-determined variables — including the first lag of sales on the assumption it is predetermined rather than endogenous did not affect the results).

Arellano-Bond tests of serial correlation in the errors yielded the expected results in all estimations - that is, tests reject a hypothesis of no first-order autocorrelation in the residuals (a consequence of the transformation of the data), while the absence of second-order autocorrelation cannot be rejected, suggesting no residual serial correlation is present in the errors. 


\section{REFERENCES}

Acosta, Pablo, and Andrés Loza. 2005, "Short and Long-Run Determinants of Private Investment in Argentina," Journal of Applied Economics, Vol. 8, No. 2, pp. 389-406.

Arellano, Manuel, and Stephen Bond. 1995, "Some Tests of Specification for Panel Data: Monte Carlo Evidence and an Application to Employment Equations," The Review of Economic Studies, Vol. 58, No. 2, pp. 277-297.

Arellano, Manuel, and Olympia Bover. 1995, "Another Look at the Instrumental Variable Estimation of Error-Components Models," Journal of Econometrics, Vol. 68, pp. 29-51.

Bernanke, Ben S., 2007, “The Financial Accelerator and the Credit Channel," (Speech; Atlanta, Georgia: Federal Bank of Atlanta).

, "Financial Fragility and Economic Performance," 1990, The Quarterly Journal of Economics, pp. 87-114 (Cambridge, Massachusetts: MIT Press).

, and Mark Gertler, 1989, "Agency Costs, Net Worth, and Business Fluctuations," The American Economic Review, Vol. 79, No. 1, pp. 14-31.

Bond, Stephen, Julie Elston, Jacques Mairesse, and Benoît Mulkay, 1997, "Financial Factors and Investment in Belgium, France, German, and the UK: A comparison Using Company Panel Data,” NBER Working Paper No. 5900 (Cambridge, Massachusetts: MIT Press).

Campa, José, and Linda S. Goldberg, 1995, "Investment, Pass-Through and Exchange Rates: A Cross-Country Comparison,” NBER Working Paper No. 5139 (Cambridge, Massachusetts: MIT Press).

Castañeda, Gonzalo, 2003, "International Capital Markets and the Financing Choices of Mexican Firms, 1995-2000”, in Galindo and Schiantarelli, eds., 2003 Op. Cit., Ch. 7, pp. 225-258.

Chirinko, Robert S. 1993, "Business Fixed Investment Spending: Modeling Strategies, Empirical Results, and Policy Implications," Journal of Economic Literature," Vol. 1, (December) pp. 1875-1911.

De Long, J. Bradford, and Lawrence H. Summers, 1991, "Equipment Investment and Economic Growth,” The Quarterly Journal of Economics, Vol. 106, No. 2, pp. 445502 (Cambridge, Massachusetts: MIT Press).

Elosegui, Pedro, Paula Español, Demian Panigo, and Juan Sotes Paladino, 2006, "Metodologías Alternativas para el Análisis de las Restricciones al Financiamiento en 
Argentina," Document de Trabajo 2006/1 (Buenos Aires: Banco Central de la República Argentina).

Fazzari, Steven M. R. Glenn Hubbard, Bruce C. Petersen, Alan S. Blinder, James M. Poterba, 1988, "Financing Constraints and Corporate Investment," Brookings Papers on Economic Activity," Vol. 1998, No. 1, pp. 141-206 (Washington: The Brookings Institution).

Fanelli, José M., Ricardo N. Bebczuk, and Juan J. Pradelli, 2003, "Determinants and Consequences of Financial Constraints Facing Firms in Argentina," in Galindo and Schiantarelli, eds., 2003 Op. Cit., Ch. 3, pp. 71-116.

Forbes, Kristin J., 2007, "One cost of the Chilean Capital Controls: Increase Financial Constraints for Smaller Traded Firms," Journal of International Economics," Vol. 71, pp. 294-323 (Cambridge, Massachusetts: MIT Press).

Galindo, Arturo, and Fabio Schiantarelli, eds., 2003, "Credit Constraints and Investment in Latin America," Inter-American Development Bank, Washington, D.C.

Gelos, R. Gastón, and Alejandro M. Werner, 2001, "Financial Liberalization, Credit Constraints, and Collateral: Investment in the Mexican Manufacturing Sector," Journal of Development Economics," Vol. 67, (2002), pp. 1-27.

Gilchrist, Simon, and Charles P. Himmelberg, 1995, "Evidence on the Role of Cash Flow for Investment," Journal of Monetary Economics, Vol. 36, pp. 541-72. , 1998, "Investment, Fundamentals and Finance," NBER Working Paper No. 6652 (Cambridge, Massachusetts: MIT Press).

Hayashi, Fumio, 1982, "Tobin's marginal q and Average q: A Neoclassical Interpretation,” Econometrica, Vol. 50, No. 1, pp. 213-24.

Horváth, Roman, 2006, "Financial Accelerator Effects in the Balance Sheets of Czech Firms," William Davidson Institute Working Paper No. 847.

Hubbard, R. Glenn, 1998, “Capital-Market Imperfections and Investment," Journal of Economic Literature, Vol. 36, pp. 193-225.

Love, Inessa, and Lea Zicchino, 2006, "Financial Development and Dynamic Investment Behavior: Evidence from Panel VAR," The Quarterly Review of Economics and Finance, Vol. 46, pp. 190-210.

Maia, José Luis and Pablo Nicholson, 2005, "El Stock de Capital y la Productividad Total del los Factores," available from the Dirección Nacional de Programación Macroeconómica, Ministerio de Economía y Producción, Argentina. 
McCulloch, Rachel, 1989, “Japanese Investment in the United States," in David B. Audretsch and Michael P. Claudon, eds., "The Internationalization of U.S. Markets," New York University Press, New York and London.

Modigliani, Franco and Merton Miller, 1958, "The Cost of Capital, Corporation Finance and the Theory of Investment," The American Economic Review, Vol. 48, No. 3, pp. 261-297.

Mulkay, Benoit, Bronwyn H. Hall, and Jacques Mairesse, 2000, "Firm Level Investment and R\&D in France and the United States: A Comparison," NBER Working Paper No. 8038 (Cambridge, Massachusetts: MIT Press).

Roodman, David, 2006, "How to Do xtabond2: An Introduction to "Difference" and "System" GMM in Stata," Center for Global Development Working Paper No. 103.

Sánchez, Gabriel, and Inés Butler, 2007, “Inversión en Argentina: Evolución Reciente y Perspectivas," Serie de Estudios Económicos y Sociales, RE1-07-004 (Washington: Banco Interamericano de Desarrollo).

Stiglitz, Joseph E. and Andrew Weiss, 1981, "Credit Rationing in Markets with Imperfect Information," The American Economic Review, Vol. 71, No. 3, pp. 393-410. 